\title{
OUTCOMES OF DIFFERENT HEALTHCARE CONTEXTS FOR DIRECT TRANSPORT TO A TRAUMA CENTRE VERSUS INITIAL SECONDARY CENTER CARE: A SYSTEMATIC REVIEW AND META-ANALYSIS
} Teresa Williams, ${ }^{a}$ Judith Finn, ${ }^{a}$ Daniel Fatovich, ${ }^{b}$ Ian Jacobs. ${ }^{c}$

\author{
${ }^{a}$ School of Primary, Aboriginal and Rural Health Care (SPARHC), the University of Western Australia, St John \\ Ambulance (WA), Faculty of Health Sciences, Curtin University \\ ${ }^{b}$ Emergency Medicine, Royal Perth Hospital, University of Western Australia, and the Centre for Clinical \\ Research in Emergency Medicine, Western Australian Institute for Medical Research \\ ${ }^{\mathrm{C}}$ St John Ambulance (WA), and the Faculty of Health Sciences, Curtin University
}

\section{INTRODUCTION}

Trauma is the leading cause of death for all persons under the age of 44 years in developed countries. $^{1-4}$ Trauma from accidents and assaults was the fourth highest cause of death in the United States of America (USA) in 2007, accounting for $5.9 \%$ of all deaths ${ }^{5}$ and the largest loss of productive years of life. The financial cost of trauma is estimated at more than US\$224 billion annually, of which direct medical costs are estimated to be US\$117 billion per year, accounting for approximately $10 \%$ of total healthcare costs. ${ }^{5,6}$ In an attempt to reduce the unacceptable burden that serious trauma places on society, the concept of a system-wide approach to managing trauma is promoted. ${ }^{7}$

Trauma systems aim to provide comprehensive, multidisciplinary and integrated care to seriously injured patients. The fundamental tenet of trauma systems is to get "the right patient to the right hospital at the right time." ${ }^{8}$ Informed from systems in the USA, most developed countries have, or are developing, some form of trauma system. ${ }^{2,9,10}$ The American College of Surgeons have criteria for categorizing hospitals into one of four levels on the basis of resources, trauma volume, and educational and research commitment. ${ }^{11}$ Level I trauma centers operate 24 hours a day/7 days a week (24/7) to provide comprehensive trauma care, immediate availability of appropriate staff and 
equipment and are required to treat a pre-specified number of seriously injured patients per year. ${ }^{12,13}$ Level II trauma centers provide comprehensive trauma care $24 / 7$ either as a supplement to a level I trauma center or as the lead hospital in less population-dense or rural areas. ${ }^{14}$ Surgeons must be available at short notice but volume performance standards are not mandatory. Level III hospitals provide initial evaluation of the patient and manage the initial care of the majority of injured patients. A general surgeon must be promptly available for major resuscitation. ${ }^{12,13}$ Level IV centers provide initial evaluation and assessment of injured patients in rural environments, require $24 / 7$ coverage by a physician, but have no specific requirement for availability of surgeons or other specialists. Individual states designate the centers within their jurisdiction and the American College of Surgeons verifies that individual hospitals meet the requirements for a specific level of trauma center. There is no clearly stated definition of serious (or severe) trauma, but minor trauma should not be transferred from secondary centers to level I/II trauma centers. ${ }^{12}$ Criteria to determine who to transport to a trauma center in the US include physiological signs, anatomy of injury, mechanism of injury, and conditions that require special consideration. ${ }^{7,12,15}$ Many countries have developed similar $3-{ }^{16,17} 4-{ }^{18-20}$ or $5-{ }^{21}$ tiered trauma systems.

Within a trauma system, pre-hospital care is the first step in managing the trauma patient. Immediate goals are to prevent further injury, initiate resuscitation and provide timely and appropriate transport of the injured patient to the most appropriate care facility. However, EMS personnel are often faced with a decision as to whether to transport a patient directly to a Level-1 trauma center or to divert to a closer secondary center for initial resuscitation and stabilization prior to onward transfer to definitive care. Clinicians involved in the care of trauma patients tend to have strong views one way or the other as to which option is 'best'. Several reports describe improved outcomes from trauma systems ${ }^{22-27}$ but the evidence for routine direct transport to a Level I/II trauma center appears inconclusive. ${ }^{20,28-31} \mathrm{~A}$ recent systematic review and meta-analysis ${ }^{32}$ found no difference in mortality between transfer and direct admissions but significant heterogeneity across 
studies challenges valid interpretation of the pooled estimate. A source of heterogeneity is likely to be related to differences in the health care context within which trauma systems operate. For example, in the USA there is a focus on trauma center care ('scoop and run'), but in France prehospital care is largely delivered by mobile critical care teams ('stay and play'). ${ }^{14}$

We conducted a systematic review to compare hospital mortality and other patient-centred outcomes for patients with serious trauma who were transported directly to a Level I/II trauma center ('direct' group) with those transported to a health care facility before transport to the Level I/II trauma center ('transfer' group) in different health care settings. The null hypothesis was that there was no difference in patient-centered outcomes between the two groups within similar health care contexts.

\section{METHODS}

\section{Search strategy}

To identify studies eligible for review, computerized searches of bibliographic databases were performed (author TW): MEDLINE (1966-2012), EMBASE (1980-2012), CINAHL (1982-2012) and the Cochrane Library (2004-2012). Terms were mapped to the appropriate MeSH/EMTREE subject headings and "exploded": ("ambulance" OR "emergency medical services" OR "pre-hospital care" OR "medical air services") AND ("trauma" OR "trauma center") AND ("outcomes" OR "mortality" OR "survival" OR "quality of life" OR "functional outcome"). Reference lists of relevant review articles and journals were hand-searched for relevant papers.

Potential studies were those that compared seriously (or severely) injured patients transported directly or firstly to a secondary hospital and then transferred by ambulance (road or air) to level I/II trauma centers. Papers that described outcomes from all trauma cases transported to a trauma 
center were excluded unless there was a description of the severely injured. Patients who were first admitted as an in-patient to the secondary hospital and later moved to the trauma center were excluded. Most of the papers excluded these patients. Meisler ${ }^{33}$ included admissions but separation of admissions to transfers was unclear and the authors did not respond to our request for information. Papers were included if they were published in English and reported patient-centered outcomes, i.e. hospital mortality, survival, quality of life and functional outcomes. Studies with ambulance response times and intensive care unit (ICU) or hospital length of stay (LOS) as the only outcomes were not included. Studies were limited to comparative studies, with concurrent controls. Those that only compared transferred patients to outcomes of a reference population or mortality case reviews were excluded. ${ }^{34-37}$ Papers had to be published in peer-reviewed journals but those published only in abstract form were excluded. No time limits on journal publication date were set. If reports described overlapping study populations, we retained the most recent or complete publication..$^{20,28,38-40}$ In some studies, only subsets of patients met the inclusion criteria, and only these subsets were included. For example, for studies that described outcomes for Injury Severity Score ${ }^{41}[$ ISS $]>15$ and ISS $=<15$, only patients with ISS $>15$ were considered. ${ }^{42}$

\section{Study selection}

Studies identified during the literature search were assessed for relevance to the review based on the information contained in the title, abstract and subject descriptor/MeSH heading (authors TW and JF). Full text articles were obtained if, after reviewing the abstract, the study was considered relevant or if the title and abstract were inconclusive. All citations selected by either author for abstract review were eligible for selection, and any subsequent disagreement regarding eligibility resolved by discussion and consensus involving a third author (IJ).

\section{Data extraction}


Data were extracted from studies that met the inclusion criteria: study design, patient characteristics, reported outcomes, direction (and magnitude) of support for the hypothesis, and relevance to the specific question asked. They were grouped into regions defined a priori, i.e. USA, Canada, Europe, Australia and New Zealand, Asia and other. They were assessed for methodological quality, i.e. confidence that the "trial design, conduct and analysis has minimized or avoided biases in its treatment comparisons", ${ }^{43}$ by the two reviewers independently (authors TW and JF).

The Newcastle-Ottawa tool (NOS), ${ }^{44}$ developed for the assessment of methodological quality of cohort studies, was also used to assess methodological quality. A star system for assessment provides a visual semi-quantitative assessment of study quality: the highest quality studies are awarded a maximum of one star for each item within the selection and outcome categories and a maximum of two stars for comparability. Studies had to achieve at least five of the nine stars to be included in this review.

\section{Data synthesis}

Narrative and tabular summaries of study characteristics, methods and results are presented, guided by the Preferred Reporting Items for Systematic Reviews and Meta-Analyses (PRISMA) statement. ${ }^{45}$ The systematic review protocol was not registered. We proposed to assess heterogeneity first, and only estimate a pooled effect if the statistical heterogeneity was low. In the event of significant heterogeneity, forest plots would be simply used to provide a graphical representation of the data. Data were analysed using Review Manager (RevMan) version 5.1 (Cochrane Collaboration, Oxford, UK) and STATA (Release 12: StataCorp LP, College Station, TX, USA). Statistical significance was defined by a two-sided alpha of 0.05 .

\section{Publication bias}


Mortality data from the studies were used to construct a funnel plot, to investigate the likelihood of overt publication bias. ${ }^{46,47}$ Funnel plot asymmetry was tested using the Harbord test for small-study effects, a modified linear regression test for funnel plot asymmetry based on the efficient score and its variance, Fisher's information. ${ }^{48}$ We also explored other reasons for asymmetry such as selection bias, methodological quality and heterogeneity.

Statistical heterogeneity was assessed using the Higgins $I^{2}$ test, ${ }^{49}$ which estimates the variability due to heterogeneity rather than chance alone. Values less than $25 \%$ are considered low risk, $25-50 \%$ moderate risk and $\mathrm{I}^{2}$ values greater than $50 \%$ high risk of heterogeneity. ${ }^{49} \mathrm{~A}$ priori sensitivity analyses were proposed to explore sources of heterogeneity in the main analysis. Pre-planned analyses included the following sub-groups: (1) patients with significant head injury (GCS $=<8) ;(2)$ those from rural areas and (3) paediatrics only. We also used the Galbraith plot, a graphical representation of the study data used to show the effect of study outliers on heterogeneity. For $95 \%$ of studies, it is expected that this is within two units of the true or population effect. ${ }^{50}$

\section{RESULTS}

\section{Study characteristics}

The initial search revealed 5,001 studies, but 4,886 were excluded after deleting duplicates and reviewing the title and abstract, and 85 excluded after reviewing the paper (Figure 1). Thirty studies $^{17,18,20,21,28-30,42,51-71}$ met the selection criteria and were included in this systematic review. We excluded ten studies ${ }^{72-81}$ because they included all trauma cases and did not describe the severely injured cohort and one study because of discrepancies in their data ${ }^{33}$ We included the most recent paper of two published by Haas, ${ }^{19,21}$ but performed a sensitivity analysis to examine the effect of including the 2010 paper rather than the 2012 paper.

Insert Figure 1 here 


\section{Study design}

No randomized controlled trials (RCT) were found in our literature search. Observational cohort studies were used to compare outcomes for patients admitted directly to the level I/II trauma center or transferred from a secondary hospital. The majority of studies abstracted data from a trauma registry database. ${ }^{18,20,28,30,53,55,59,60,64,65,67,70,71,82}$ Young ${ }^{71}$ checked missing registry data with the patients' medical records. Registry data were collected prospectively and analysed retrospectively and in most studies patients who died at the scene were not included. Record linkage was used in two studies to link administrative databases with ${ }^{51}$ and without ${ }^{21}$ trauma registry data. Databases from other sources were used in nine studies ${ }^{29,52,54,57,58,61-63,66}$ Retrospective review of medical records was performed in five studies. ${ }^{17,42,56,68,69}$

The majority of studies were conducted in single level I/II trauma centers and their catchment areas, but eight were multiple level I/II centers studies: three from the USA, ${ }^{53,54,63}$ three from Canada ${ }^{21,28,51}$ one from Italy ${ }^{62}$ and one from Australia. ${ }^{30}$ Four USA studies ${ }^{67,70,71,83}$ and one Norwegian study ${ }^{68}$ classed their catchment area as 'rural'.

Most of the studies ( $n=14,47 \%$ ) were from the USA ${ }^{18,20,29,53-55,57,60,63,64,67,69-71}$ Three were from Canada, ${ }^{21,28,51}$ six from Europe that included two from Norway, ${ }^{17,68}$ two from the Netherlands, ${ }^{58,82}$ one from Italy ${ }^{62}$ and one from Switzerland, ${ }^{65}$ four from Asia (Hong Kong, ${ }^{42,66}$ Japan, $^{61}$ and Taiwan ${ }^{56}$ ), two from Australia and New Zealand ${ }^{30,59}$ and one from South Africa. ${ }^{52}$ The mean age of patients varied between regions, from an overall median age of 27 years in the South African study ${ }^{52}$ to 44.9 years for the direct group and 45.9 years for the transfer group in the three Canadian studies. ${ }^{21,28,51}$ 
There was considerable variation between studies in the structure, policies and practices of the respective trauma system (Table 1 ). In the USA, four-tiered systems were common $20,29,53,54,57,63,64,69,71$ but this was not consistent. For example, at the time of the study, no formal tiered trauma system was described by several papers including from the USA, ${ }^{18,67}$ Asia, ${ }^{42,56}$ New Zealand, ${ }^{59}$ and South Africa. ${ }^{52}$ In Canada the trauma system varied by province. ${ }^{21,28,51}$ Three-tiered systems were described in Europe, ${ }^{17,58,68}$ and Australia. ${ }^{30}$ Two-tiered systems were also described in Europe ${ }^{62,65,82}$ and Japan. ${ }^{61}$ Insert Table 1 here

The policy for the management of patients with serious trauma also varied. In some trauma systems, patients with serious trauma were transported to a level I/II trauma center, bypassing closer secondary hospitals ${ }^{20,54,57}$ whereas other systems transported patients to the nearest ED for stabilisation before transfer to a level I/II trauma center..$^{28,51,59,69,82}$ In some trauma systems the transfer policy varied according to the severity of the trauma or the proximity of the trauma center. For example, patients with serious injury, as triaged at scene by EMS personnel were transported to the trauma center if transportation was estimated to be less than 20 minutes. ${ }^{18,30}$ Some studies did not indicate whether written protocols specifying direct transport or transport to a secondary center then transfer to a Level I/II trauma center were available. ${ }^{29,52,56,63,67,71}$

Transport was most often by road ambulance for studies that reported mode of transportation ${ }^{18,20,28,30,42,54,58,61}$ or combination of road and air services. ${ }^{17,51,52,55,57,59,62,67,71,84}$ Two studies, one from the USA ${ }^{60}$ and the other from Norway ${ }^{68}$ described air-based services only.

\section{Missing data}

Missing data were reported in ten studies, ${ }^{18,21,42,53,54,59,63,64,68,82}$ which ranged from less than $1 \%$ to $33 \%$ and these cases were excluded from their analyses. de Jongh ${ }^{82}$ reported $33 \%$ missing data but the proportion of these who had severe trauma was not reported. A large amount of pre-hospital 
blood pressure data was missing but was replaced by day 1 systolic blood pressure values taken from the in-hospital records and used in multivariate analyses to control for hypotension in a study on TBI. ${ }^{54}$ Multiple imputation to account for missing data on comorbidity and mechanism of injury were undertaken by Rivara ${ }^{29}$ in survival analysis of one-year follow-up, Garwe ${ }^{53}$ in their propensityadjusted survival analyses and Fatovich ${ }^{30}$ in their regression modelling of mortality. 


\section{Methodological quality}

The NOS $^{44}$ ranged from 5 to 9 (mean 7). No study was excluded because of methodological quality.

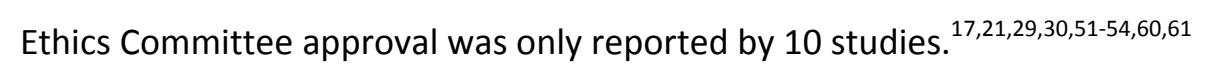

\section{Sample size}

Of the 43,554 patients included in this review, 31,261 (72\%) patients had a direct admission to a level I/II trauma center. Nineteen studies ${ }^{17,42,51,52,56-62,64-66,68-71,82}$ had fewer than 1,000 patients, ten, (seven from the US, ${ }^{18,20,53-55,63,67}$ two from Canada ${ }^{21,28}$ and one from Australia ${ }^{30}$ ) had between 1,000 and 5,000 patients and one study from the $\mathrm{US}^{29}$ had more than 10,000 patients. No study described their study power calculation. With the exception of four studies ${ }^{51,52,56,60}$ that had a greater proportion of transfers than direct admissions, the proportion of direct admissions to transfers ranged from $6 \%$ to $48 \%$ (median $33 \%)$.

\section{Publication bias}

The funnel plot included all 30 studies. It was asymmetrical $(p=0.16)$, with small studies showing no benefit from the transfer group possibly missing from the analysis (Figure A Supplementary Data). A sensitivity analysis was conducted, excluding outliers, but similar results were found.

\section{Heterogeneity}

In the meta-analysis of hospital mortality overall there was high heterogeneity $\left(I^{2} 71 \%\right)$. This was decreased when grouping studies by region, ranging from $0 \%$ to $67 \%$ with the exception of the Canadian studies where the $\mathrm{I}^{2}$ value of $91 \%$ was very high. Valid interpretation of the pooled estimates could not be made for those with high heterogeneity.

Studies used different definitions for 'serious' trauma. A definition of major trauma as an ISS greater than 15 was reported in eight studies, ${ }^{18,21,30,42,55,62,71,82}$ trauma registry criteria plus other restrictions 
on entry requirements in six others. ${ }^{20,28,29,53,63,67}$ In the studies of TBI, severe TBI was defined as a GCS $<9^{17,54,57}$ or Abbreviated Injury Scale (AIS) of 3 or greater of the head score. ${ }^{58,59}$ Injury severity, as estimated from the mean ISS, was reported in several studies. The mean ISS for direct admissions versus transfer (paediatric studies excluded) in the USA studies ${ }^{18,20,53-55,63,64,70,71}$ was 19.8 and 20 respectively. In five European studies, two reported mean ISS, ${ }^{62,65}$ direct group 28.5 and transfer group 29.2 and three reported the median, ${ }^{17,58,82}$ direct group 25 and transfer group 25 . These were higher values than the other regions. No Asian study reported the mean or median ISS. The median ISS in the Australian and New Zealand studies was 20 in the direct group and 20.5 in the transfer group, similar to the USA studies. Cheddie ${ }^{52}$ reported a median ISS of 25 in the direct group and 20 for the transfer group. Four studies ${ }^{21,29,42,61}$ reported the proportion of patients with ISS $>=16$. In an USA study ${ }^{29} 77 \%$ of patients in both groups had a NISS $>=16$. In a second study from Japan ${ }^{61} 68 \%$ of the direct group and $81 \%$ of the transfer group had an ISS $>=16$. Haas ${ }^{21}$ grouped their patient ISS into three categories, with a higher proportion of patients having higher ISS in the direct group but there was a greater number of patients with missing ISS in the transfer group. There was a higher proportion of patients with ISS $>40$ in the direct group in a Hong Kong study. ${ }^{42}$

The Galbraith plot showed that eleven of the studies ${ }^{18,20,21,28-30,54,57,60,66,69}$ were outside the $95 \%$ limits of studies that are expected to have effect estimates within two standard errors of the population effect confirming significant heterogeneity (Figure B Supplementary Data). Six of these studies $^{18,20,21,28,29,30}$ were large studies with sample sizes greater than 3,000 patients.

\section{Patient mortality}

Different time points were used for mortality assessment with hospital mortality that included the deaths in the Level I/II trauma center ED (and not the transferring hospitals' EDs) the most frequent time point for 13 US studies, ${ }^{18,20,29,55,57,60,63,64,67,69-71}$ two Canadian studies, ${ }^{28,51}$ one European study, ${ }^{65}$ the four Asian studies, ${ }^{42,56,61,66}$ the two Australian / New Zealand studies ${ }^{59}$ and the South African 
study.$^{52}$ Cheddie ${ }^{52}$ also reported hospital mortality for patients who survived longer than 12 hours. Hospital mortality was lower in the transfer group if patients who did not survive the first 12 hours were included but significantly higher when excluding these deaths. Including deaths at the secondary hospital, Fatovich ${ }^{30}$ reported similar mortality between direct admissions and transfers when including deaths in the secondary hospitals but lower mortality in transfers when excluding these deaths. In a USA study, Garwe ${ }^{53}$ reported higher 30-day mortality for transfers when including ED deaths in the secondary hospitals compared to lower mortality when excluding them. Thirty day mortality was reported by four studies (USA, ${ }^{53}$ Canada, ${ }^{21}$ Europe $^{58,82}$ ). Haas $^{21}$ also reported ED, 24hour, 48-hour and 7-day mortality. Other time points included ICU mortality reported by one Italian study, ${ }^{62}$ two week mortality in an US study of $\mathrm{TBI}^{54}$ six-month mortality in a Norwegian study of $\mathrm{TB} \mathrm{I}^{17}$ and one-year survival in an USA study. ${ }^{29}$

The pooled estimate for the 30 combined studies showed a non-significant, reduced risk of dying for the transfer group compared to direct admissions to the Level I/II trauma center (OR $0.91,95 \% \mathrm{Cl}$ $0.77-1.08)$ but there was high heterogeneity $\left(1^{2} 71 \%\right)$. Large variation in the unadjusted mortality was reported, as shown in Figure 2.

Insert Figure 2 here

US Studies

In the studies conducted in the USA (Figure 2a) direct admission was slightly favored (OR 1.04, 95\% $\mathrm{Cl} 0.85-1.29)$ but there was high statistical heterogeneity $\left(I^{2}=67 \%\right)$. For rural settings, ${ }^{55,67,70,71}$ transfer was associated with lower mortality (OR $\left.0.87,95 \% \mathrm{Cl} 0.60-1.25, \mathrm{I}^{2} 30 \%\right)$. Excluding studies that were conducted more than ten years ago and rural settings, there was no statistical heterogeneity $\left(I^{2}=0 \%\right)$ and direct transport was favored $(\mathrm{OR}=1.23,95 \% \mathrm{Cl}$ 1.03-1.47). For studies of $\mathrm{TBI}$, there was a significant reduction in the risk of dying in the direct group (OR 2.05, 95\% Cl 1.09-3.85, $\left.\mathrm{I}^{2} 65 \%\right)^{54,57,69}$ but similar to the USA studies overall, high heterogeneity. Hartl's ${ }^{54}$ study of TBI reported missing pre- 
hospital blood pressure data in $47 \%$ of patients. The missing values were substituted with day 1 values. Our meta-analysis did not assess the results from the multivariate analyses in the systematic review. Excluding this study, direct transport to a Level I/II trauma center was favored but the effect size was smaller (OR $1.0295 \% \mathrm{Cl}$ 0.81-1.28). Two US studies ${ }^{53,54}$ reported 24 hour to 14 -day mortality and showed direct transfer was associated with a decreased risk in dying. Paediatric-specific studies were only reported in the USA. The study of $\mathrm{TBI}^{57}$ supported direct admission and a study of severe trauma found transfer associated with reduced risk of dying. ${ }^{60}$

\section{Canadian studies}

The three studies from Canada (Figure $2 \mathrm{~b}$ ), conducted in three different provinces, had high statistical heterogeneity $\left(I^{2}=91 \%,\right)$. The studies favoring transfer were conducted among burns patients in $2006^{51}$ and injuries from motor vehicle crashes ${ }^{21}$ between 2002 and 2010. The third Canadian study ${ }^{28}$ favored direct transport to a level I trauma center and was conducted shortly after the introduction of trauma systems in Canada between 1993 and 1995. There was little difference in the pooled estimate when data from Haas ${ }^{19}$ study data were used rather than the more recent paper. ${ }^{21}$

\section{European studies}

In Europe the pooled effect favored transfer (OR $0.91,95 \% \mathrm{Cl} 0.64-1.30, \mathrm{I}^{2}=30 \%$ ) but this was not significant (Figure 2c). Excluding de Jongh's study ${ }^{82}$ because of a third of eligible patients were excluded did not change the result substantially (OR $0.98,95 \% \mathrm{Cl} 0.65-1.48$ ). Moen ${ }^{17}$ reported 6month mortality and when this study was excluded, the pooled effect demonstrated a nonsignificant support for direct admission to the trauma center (OR 1.03, 95\% $\mathrm{Cl} 0.76-1.40, \mathrm{I}^{2}=0 \%$ ). Excluding the three severe TBI studies ${ }^{17,58,68}$ the pooled effect favored direct transport to a Level I trauma center but the difference between direct and transfer modes was not significant (OR 1.05, $\left.95 \% \mathrm{Cl} 0.71-1.56, \mathrm{I}^{2}=26 \%\right)$. 


\section{Asian studies}

The pooled estimate from the four Asian studies favored direct transport to a trauma center but statistical heterogeneity was high $\left(I^{2}=73 \%\right)$. The study conducted by Poon and $\mathrm{Li}^{66}$ of 104 patients with traumatic extradural haematoma had very wide confidence intervals. Excluding this study, conducted between 1985 and 1989, reduced statistical heterogeneity substantially and the pooled effect was associated with a reduced risk of dying in the transfer group (OR 0.75, 95\% $\mathrm{Cl} 0.50-1.13$, $\left.1^{2}=0 \%\right)$, as shown in Figure $2 \mathrm{~d}$.

\section{Australasian studies}

In the two Australia / New Zealand studies, the pooled effect significantly favored transfers (OR 0.60, $\left.95 \% \mathrm{Cl} 0.49-0.74, \mathrm{I}^{2} 0 \%\right)$ and in the South African study there was also a tendency for patients transported first to a secondary hospital to have a reduced risk of dying (OR $0.98,95 \% \mathrm{Cl} 0.61-1.59$ ).

Fourteen studies (seven US, ${ }^{18,20,29,53,54,63,67}$ three Canadian studies, ${ }^{21,28,51}$; two European, ${ }^{17,82}$ one Asian ${ }^{56}$ and one Australian study ${ }^{30}$ ) adjusted for independent predictors of mortality such as age, gender, ISS, mechanism of injury, comorbidity. Three USA studies ${ }^{53,54,63}$ and two Canadian studies ${ }^{21,28}$ reported an independent and significant increase in the risk of death in the transfer group. Garwe $^{53}$ examined mortality at 24 hours, $>24$ hours to 14 days and $>14$ days to 30 days but the increased risk of dying in the transfer group was only significant at $>24$ hours to 14 days. Harrington ${ }^{18}$ reported higher unadjusted mortality in the transfer group but in the multivariate analysis directness of transport was not significant.

\section{Other patient-centred outcomes}

Other patient-centred outcomes were reported in six studies. ${ }^{17,55,58,66,68}$ In two studies ${ }^{17,68,69}$ the Glasgow Outcome Scale (GOS) was used to assess outcome: a score of 4-5 was categorised as a 
favorable outcome and GOS 1-3 as an unfavorable outcome. Moen ${ }^{17}$ showed higher age, low field Glasgow Coma Scale and bilateral dilated pupils were independent predictors of unfavorable GOS at six months, but being in the transfer group did not predict patient outcome. Sollid ${ }^{68}$ found no difference in the proportion of good GOS outcomes ( $58 \%$ transfer versus $53 \%$ direct group). The direct group had a worse GOS on-scene but did not differ overall $(p=0.87)$ in Joosse's study. ${ }^{58}$ Among patients with acute subdural haematoma functional recovery was higher in the direct group (33\%) compared to $15 \%$ in the transfer group but severe disability was higher in the direct group (17\%) versus $9 \%$ for the transfer group. ${ }^{69}$

Helling ${ }^{55}$ assessed Functional Independence Measure Scores (FIM) Scores for feeding transfer ability, locomotion, verbal expression and social interaction. ${ }^{85}$ Scores ranged from 1 (complete dependence) to 4 (complete independence). With the exception of verbal expression, the scores were higher in the direct group. Poon and $\mathrm{Li}^{66}$ found moderate or severe disability was less in the direct group, $10 \%$ compared to $27 \%$ in the transfer group.

\section{DISCUSSION}

We found differences in health care context and associated case-mix both within countries and between countries were important, such as different proportions of penetrating and blunt trauma. ${ }^{14}$ This may be influential, as the majority of the studies were from the USA. Pre-hospital triage decisions are likely to depend on the need for immediate resuscitation, geographic distances between the scene and closest local hospital or level I/II trauma center and the time intervals involved, the expertise of the attendants (volunteer, paramedic, physician), facilities available at the closest hospital; and individual EMS personnel preferences. ${ }^{16}$ 
Inconsistent results were found when pooling the data from all included studies ${ }^{17,18,20,21,28-30,42,51-71,82}$ : favorable outcomes were significantly higher for patients directly transported to a level I/II trauma center in some studies, lower in other studies while the remaining studies found no difference. After adjustment for independent risk factors for death, the effect of transfer on outcomes also remained inconclusive.

The pooled estimates of all studies combined demonstrated significantly high statistical heterogeneity $\left(I^{2} 71 \%\right)$; similarly reported in a recently published systematic review. ${ }^{32}$ This statistical heterogeneity reflects the clinical heterogeneity of serious trauma. Several factors may explain some of the inconsistency of outcomes between studies such as trauma system structure, triage policies, pre-hospital care and the method of assessing patient outcomes. For example, there are differences in the EMS services provided. Paramedic based systems are common in the USA, Australia and the UK but may offer basic or advanced life support and administer different interventions. Pre-hospital physician-manned EMS are well developed in Scandinavia and other European countries and widely used to supplement paramedic-based EMS. ${ }^{86}$ We hypothesized that the health care context could explain some of the heterogeneity and that similar health care contexts grouped together may enable a more valid interpretation of the meta-analysis.

We also found the association of "directness" to a level I/II trauma center on mortality for patients with serious trauma varied across different health care contexts. Some regions had high heterogeneity challenging the validity of the pooled estimates. Combining studies from the USA. ${ }^{18,20,29,53-55,57,60,63,64,67,69-71}$ there was high heterogeneity but the studies were conducted at different time periods, ranging from $1969-1981^{69}$ to $2006-2007^{53}$ when trauma systems were at different stages of their evolution and this may influence patient outcomes. ${ }^{87}$ In the last ten years (excluding rural trauma systems) there have been only four studies conducted in the USA ${ }^{18,53,54,63}$ Combining these studies, we found no heterogeneity $\left(I^{2}=0 \%\right)$. Direct admission to a level $I / I I$ trauma 
center was associated with a $23 \%$ reduction in mortality compared to transfers. We found high heterogeneity in the three Canadian studies ${ }^{21,28,51}$ which is not surprising considering the different trauma systems operating in each of the three provinces. Sampalis' study ${ }^{28}$ was conducted between 1993 and 1995, shortly after the introduction of their trauma system. When this study was excluded, there heterogeneity was low and a trend towards direct admission being associated with a reduced risk of mortality. The Canadian trauma system was modeled on the USA system and started in the early 1990s in Quebec. Other provinces have followed and as a consequence Canada has a relatively mature trauma system.

The six European studies $17,58,62,65,68,82$ included in our systematic review have modified their trauma systems from the USA system to accommodate their health care contexts. The two Norwegian studies described outcomes of TBI and used different time points for assessment of mortality. The results from both studies favored transfer. Similarly, the combination of the six European studies in the meta-analysis demonstrated a non-significant trend for transfers being associated with a nine percent reduction in mortality and moderate heterogeneity. Exclusion of Moen's study ${ }^{17}$ that reported six-month mortality, compared to hospital or 30-day mortality in the other studies, reduced heterogeneity. There was a non-significant, three percent reduction in mortality for direct admissions.

Considering the four Asian studies, ${ }^{42,56,61,66}$ two described outcomes of TBI patients. ${ }^{56,66}$ There was high heterogeneity when combing the studies. Poon and Li's study ${ }^{66}$ of traumatic extradural haematoma conducted between 1988 and 1989 had very wide confidence intervals. When excluded from the meta-analysis, heterogeneity was low and there was a trend for lower risk of dying in the transfer group. This result was heavily weighted by Hsiao's TBI study which was surprising because other studies of $\mathrm{TBI}^{54,57-59}$ have shown a survival advantage of direct admission. 
Australia has tertiary referral centers in the major capital cities designated either major trauma hospitals (level 1) or metropolitan trauma hospitals (level 2); rural-based hospitals, which are larger regional centers and rural district hospitals, with a smaller number of beds, usually staffed by general practitioners, although occasionally surgeons are available. ${ }^{9,16,88,89}$ Not all of the eight States and Terrorities have formal trauma systems. Only two studies met the selection criteria. There was a reduction in mortality for patient transfers in the meta-analysis that was heavily weighted by the Australian study conducted by Fatovich. ${ }^{30}$ Further studies are required to see if this trend continues as trauma systems mature.

Trauma centers have been shown to have better outcomes ${ }^{1,23}$ but the factors contributing to their success are largely unknown ${ }^{31}$. Shafi ${ }^{90}$ reported institutional variations in patient outcomes but found no significant associations between centers by performance ranking or trauma center characteristics. Survival for patients with penetrating injuries with shock and severe TBI with mass effect was improved when managed at Level I trauma centers although the more rapid assessment or earlier intervention at the Level I trauma center were not important. ${ }^{91}$ Increased expertise in managing these patients is important but processes of care likely to influence outcome are difficult to measure. ${ }^{91}$

The decision to advocate bypass of closer secondary hospitals if they have the expertise and resources to provide quality care and stabilise the patient prior to transfer to a trauma center remains uncertain. Patients who require immediate resuscitation may deteriorate during the extra time required to reach the more distant trauma center. Stabilising patients before being transported to definitive care at the level I/II trauma center may reduce the time patients suffer physiological derangement and its consequences. Garwe ${ }^{92}$ found patients were less likely to be transported directly to a Level I trauma center if they were further away from the Level I trauma center, 
required advanced airway management or had higher GCS scores (less likely to have a head injury). ${ }^{92}$

Several studies in our review ${ }^{19,20,63}$ excluded transfers from non-trauma centers, a source of potential bias. Deaths for direct admissions to a trauma center are typically included in the mortality rate but estimates of mortality are inherently biased because patients dying at the secondary hospital are not usually included. ${ }^{29,30}$ It is preferable to include ED deaths at the transferring hospital but Fatovich ${ }^{30}$ found the significant differences in crude hospital mortality were removed when including deaths at the secondary hospital, even after adjusting for this selection bias.

Mortality is known to vary with age, severity of illness and mechanism of injury, but these were not reported consistently and there was no independent adjustment for important risk factors in several of the studies in this systematic review. Two large studies from the USA ${ }^{18,20}$ had a disproportionately large number of direct admissions and fewer patients transferred from a secondary center (16:1 and $12: 1$, respectively) suggesting compliance with a directive that serious trauma should be transported directly to the level I/II trauma center. Nevertheless, unadjusted mortality in the transfer group was lower in one ${ }^{20}$ and higher in the other study ${ }^{18}$ and when adjusted for potential risk factors no difference was found. Other studies also show considerable variability in risk-adjusted mortality between similarly designated trauma centers..$^{90,93,94}$

There is also little information on the effect of the quality of resuscitation provided in the secondary hospital's ED before transfer to the level I/II trauma center on patient outcomes. Gomes ${ }^{95}$ found that pre-hospital interventions to treat life-threatening events may significantly decrease mortality when compared to similar interventions performed later at the trauma center. 
This systematic review has several limitations. It is possible that we have missed some papers, despite an exhaustive literature search. It is also possible that the results are confounded by the fact that patients transferred directly to a level 1 trauma center may be different to those not directly transported in a way that has not been identified by the studies, or that the prehospital transport decisions have led to a selection bias. Also, due to evolution in trauma care over decades, it is likely that the many variables important in trauma care have changed over time.

Ideally a RCT would be used to test the hypothesis but, to our knowledge, no RCT has been conducted. All the studies in this review were cohort studies that have inherent biases due to the non-random allocation of the intervention. However, the use of concurrent controls reduces the bias compared with before and after studies that use historical controls. By comparing the outcome of direct admissions with transfer patients from the same level I/II trauma center, the effect of patient care is less likely to confound the results. ${ }^{96} \mathrm{~A}$ common study method was to use trauma registry data but trauma registries use different definitions for inclusion and systematically exclude patients who die before transfer ${ }^{19}$ making comparison between studies difficult.

One method of standardising definitions is the Utstein Trauma Template for Uniform Reporting of Data following Major Trauma ${ }^{97}$ that uses uniform documenting and reporting of data following serious trauma to evaluate outcomes and enable comparisons between studies. No studies in this systematic review used this template. For a definitive answer to the study question, it is likely that a comprehensive nationwide trauma registry, with systematic data collection methods from the prehospital environment to hospital discharge and beyond, will be needed so that the many variables may all be accounted for in comparisons between tens of thousands of patients. Until that time, this study may be the best available evidence in regards to this contentious topic that highlights the complexities of the research question. 


\section{CONCLUSION}

The published scientific evidence does not provide a definitive answer about the effect of direct transport to a level I/II trauma center compared with initial transport to another hospital for stabilisation first. Consideration needs to be given to differences in the overall healthcare context, the quality of care available within the local trauma system (including pre-hospital services) and the local epidemiology of injury in the interpretation of research in this complex field. Adherence to the Utstein template for major trauma will facilitate interpretation of the results from different centers. The current evidence is unable to support or refute a conclusion that all trauma patients be routinely transported directly to a level I/II trauma center. Perhaps our main finding is that the heterogeneity is so great that it is not possible to definitively answer the study question at this time. This challenges currently accepted dogma. However, each patient's situation and injuries are unique.

\section{ACKNOWLEDGEMENT}

We wish to thank Michael Phillips, biostatistician, Western Australian Medical Institute of Research, for his advice on the statistical analysis.

\section{CONFLICT OF INTEREST STATEMENT}

TAW is a NH\&MRC Clinical Research Postdoctoral Fellow

JF receives partial salary support from St John Ambulance (WA)

DF - no conflict of interest

IJ is the Clinical Services Director for St John Ambulance (Western Australia). 
St John Ambulance (WA) played no role in the study design, conduct or interpretation of the results.

\section{REFERENCES}

1. MacKenzie EJ, Weir S, Rivara FP, Jurkovich GJ, Nathens AB, Wang W, Scharfstein DO, Salkever DS. The value of trauma center care. J Trauma. 2010;69:1-10.

2. Trauma Association of Canada (2007). Trauma System Accreditation Guidelines. Available from http://sp.ontariotrauma.ca/Accreditation\%20Documents/Accreditation Guidelines Jun 07. pdf. Accessed Oct 2011.

3. National Audit Office (2010). Major trauma care in England. Avaliable from http://www.nao.org.uk/publications/0910/major trauma care.aspx Accessed Dec 2012.

4. Australian Institute of Health and Welfare (2010). Australia's Health 2010. Australia's Health Series no. 12. Cat. no. AUS 122. . Canberra: AlHW.

5. Xu J, Kochanek K, Murphy S, Tejada-Vera B. Deaths: Final Data for 2007 in US DEPARTMENT OF HEALTH AND HUMAN SERVICES Centers for Disease Control and Prevention National Center for Health Statistics National Vital Statistics Reports. In: vol 58 no 19. Hyattsville, MD: National Center for Health Statistics. 2010.

6. US Department of Health and Human Services (2006). Model Trauma System. Planning and Evaluation. Available from ftp://ftp.hrsa.gov/hrsa/trauma/traumamodel.pdf. Accessed Aug 2011.

7. Sasser SM, Hunt RC, Faul M, Sugerman D, Pearson WS, Dulski T, Wald MM, Jurkovich GJ, Newgard CD, Lerner EB, Centers for Disease Control and Prevention. Guidelines for field 
triage of injured patients: recommendations of the National Expert Panel on Field Triage, 2011. MMWR Recomm Rep. 2012;61:1-20.

8. American College of Surgeons Committee on Trauma. Resources for Optimal Care of the Injured Patient. . Chicago, III: American College of Surgeons; 1993.

9. $\quad$ Delprado AM. Trauma systems in Australia. J Trauma Nurs. 2007;14:93-7.

10. Leppaniemi A. A survey on trauma systems and education in Europe. Eur J Trauma Emerg Surg. 2008;34:571-88.

11. United States Department of Health and Human Services (2006). Health Resources and Services Administration, Trauma-EMS Systems Program. Model trauma system planning and evaluation. Available http://www.hrsa.gov/trauma/model.htm. Accessed Oct 2011.

12. American College of Surgeons Committee on Trauma (2006). Resources for optimal care of the injured patient. Chicago: American College of Surgeons.

13. MacKenzie EJ, Hoyt DB, Sacra JC, Jurkovich GJ, Carlini AR, Teitelbaum SD, Teter H, Jr. National inventory of hospital trauma centers. Jama. 2003;289:1515-22.

14. Nathens AB, Brunet FP, Maier RV. Development of trauma systems and effect on outcomes after injury.[Erratum appears in Lancet. 2005 Nov 19;366(9499):1772]. Lancet. 2004;363:1794-801.

15. Sasser SM, Ossmann E, Wald MM, Lerner EB, Hunt RC. Adoption of the 2006 field triage decision scheme for injured patients. West J Emerg Med. 2011;12:275-83.

16. Atkin C, Freedman I, Rosenfeld JV, Fitzgerald M, Kossmann T. The evolution of an integrated State Trauma System in Victoria, Australia. Injury. 2005;36:1277-87.

17. Moen KG, Klepstad P, Skandsen T, Fredriksli OA, Vik A. Direct transport versus interhospital transfer of patients with severe head injury in Norway. Eur J Emerg Med. 2008;15:249-55. 
18. Harrington DT, Connolly M, BiffI WL, Majercik SD, Cioffi WG. Transfer times to definitive care facilities are too long: a consequence of an immature trauma system. Ann Surg. 2005;241:961-6.

19. Haas B, Gomez D, Zagorski B, Stukel TA, Rubenfeld GD, Nathens AB. Survival of the fittest: the hidden cost of undertriage of major trauma. J Am Coll Surg. 2010;211:804-11.

20. Nathens AB, Maier RV, Brundage SI, Jurkovich GJ, Grossman DC. The effect of interfacility transfer on outcome in an urban trauma system. J Trauma. 2003;55:444-9.

21. Haas BMD, Stukel TAP, Gomez DMD, Zagorski BM, De Mestral CMD, Sharma SVMD, Rubenfeld GDMDM, Nathens ABMDPF. The mortality benefit of direct trauma center transport in a regional trauma system: A population-based analysis. J Trauma 2012;72:15107.

22. Mackenzie EJ, Rivara FP, Jurkovich GJ, Nathens AB, Egleston BL, Salkever DS, Frey KP, Scharfstein DO. The impact of trauma-center care on functional outcomes following major lower-limb trauma. J Bone Joint Surg Am. 2008;90:101-9.

23. MacKenzie EJ, Rivara FP, Jurkovich GJ, Nathens AB, Frey KP, Egleston BL, Salkever DS, Scharfstein DO. A national evaluation of the effect of trauma-center care on mortality. $N$ Engl J Med. 2006;354:366-78.

24. Tinkoff GH, Reed JF, 3rd, Megargel R, Alexander EL, 3rd, Murphy S, Jones MS. Delaware's inclusive trauma system: impact on mortality. J Trauma. 2010;69:245-52. 25. Cameron PA, Gabbe BJ, Cooper DJ, Walker T, Judson R, McNeil J. A statewide system of trauma care in Victoria: effect on patient survival. Med J Aust. 2008;189:546-50.

26. Celso B, Tepas J, Langland-Orban B, Pracht E, Papa L, Lottenberg L, Flint L. A systematic review and meta-analysis comparing outcome of severely injured patients 
treated in trauma centers following the establishment of trauma systems. J Trauma. 2006;60:371-8.

27. Nathens AB, Jurkovich GJ, Rivara FP, Maier RV. Effectiveness of state trauma systems in reducing injury-related mortality: a national evaluation. J Trauma. 2000;48:25-30.

28. Sampalis JS, Denis R, Frechette P, Brown R, Fleiszer D, Mulder D. Direct transport to tertiary trauma centers versus transfer from lower level facilities: impact on mortality and morbidity among patients with major trauma. J Trauma. 1997;43:288-95.

29. Rivara FP, Koepsell TD, Wang J, Nathens A, Jurkovich GA, Mackenzie EJ. Outcomes of trauma patients after transfer to a level I trauma center. J Trauma. 2008;64:1594-9.

30. Fatovich D, Phillips M, Jacobs I. A comparison of major trauma patients transported to trauma centres vs. non-trauma centres in metropolitan Perth. Resuscitation. 2011;82:560-3.

31. Capone-Neto A, Rizoli SB. Linking the chain of survival: trauma as a traditional role model for multisystem trauma and brain injury. Curr Opin Crit Care. 2009;15:290-4.

32. Hill AD, Fowler RA, Nathens AB. Impact of interhospital transfer on outcomes for trauma patients: a systematic review. J Trauma. 2011;71:1885-900.

33. Meisler R, Thomsen AB, Abildstrom H, Guldstad N, Borge P, Rasmussen SW, Rasmussen LS. Triage and mortality in 2875 consecutive trauma patients. Acta Anaesthesiol Scand. 2010;54:218-23.

34. West JG, Cales RH, Gazzaniga AB. Impact of regionalization. The Orange County experience. Arch Surg. 1983;118:740-4.

35. West JG, Trunkey DD, Lim RC. Systems of trauma care. A study of two counties. Arch Surg. 1979;114:455-60. 
36. Certo TF, Rogers FB, Pilcher DB. Review of care of fatally injured patients in a rural state: 5-year followup. J Trauma. 1983;23:559-65.

37. Guss DA, Meyer FT, Neuman TS, Baxt WG, Dunford JV, Jr., Griffith LD, Guber SL. The impact of a regionalized trauma system on trauma care in San Diego County. Ann Emerg Med. 1989;18:1141-5.

38. Liberman M, Mulder DS, Lavoie A, Sampalis JS. Implementation of a trauma care system: evolution through evaluation. J Trauma. 2004;56:1330-5.

39. Sampalis JS, Denis R, Lavoie A, Frechette P, Boukas S, Nikolis A, Benoit D, Fleiszer D, Brown R, Churchill-Smith M, Mulder D. Trauma care regionalization: a process-outcome evaluation. J Trauma. 1999;46:565-79.

40. O'Keefe GE, Jurkovich GJ, Copass M, Maier RV. Ten-year trend in survival and resource utilization at a level I trauma center. Ann Surg. 1999;229:409-15.

41. Baker SP, O'Neill B, Haddon W, Jr., Long WB. The injury severity score: a method for describing patients with multiple injuries and evaluating emergency care. J Trauma. $1974 ; 14: 187-96$.

42. Kam CW, Kitchell AK, Yau HH, Kan CH. Outcome of major trauma patients in a Hong Kong general hospital. Eur J Emerg Med. 1998;5:297-306.

43. Moher D. Facilitating clinical research in the 1990s and beyond: challenges facing clinical trial registers. Fundam Clin Pharmacol. 1995;9:381-3.

44. Wells G, Shea B, O’Connell D, Peterson J, Welch V, Losos M, Tugwell P (1998). The Newcastle-Ottawa Scale (NOS) for assessing the quality if nonrandomized studies in metaanalyses. Available from http://www.ohri.ca/programs/clinical_epidemiology/oxford.htm. Accessed Jan 2012. 
45. Moher D, Liberati A, Tetzlaff J, Altman DG, Group P. Preferred reporting items for systematic reviews and meta-analyses: the PRISMA statement. J Clin Epidemiol. 2009;62:1006-12.

46. Higgins J, Green S, (editors).(2011) Cochrane Handbook for Systematic Reviews of Interventions Version 5.1.0 [updated March 2011]. The Cochrane Collaboration, 2011. Available from www.cochrane-handbook.org. (accessed 29 Mar 2011).

47. Sterne JA, Egger M. Funnel plots for detecting bias in meta-analysis: guidelines on choice of axis. J Clin Epidemiol. 2001;54:1046-55.

48. Harbord R, Egger M, Sterne JAC. A modified test for small-study effects in metaanalyses of controlled trials with binary endpoints. Stat Med. 2006;25:3443-57.

49. Higgins JPT, Thompson SG, Deeks JJ, Altman DG. Measuring inconsistency in metaanalyses. BMJ. 2003;327:557-60.

50. Newton H, (Ed.). STATA January 1998 TECHNICAL STB-41 BULLETIN. College Station, Texas: Stata Corporation; 1998.

51. Bell N, Simons R, Hameed SM, Schuurman N, Wheeler S. Does direct transport to provincial burn centres improve outcomes? A spatial epidemiology of severe burn injury in British Columbia, 2001-2006. Can J Surg. 2012;55:110-6.

52. Cheddie S, Muckart D, Hardcastle T, den Hollander D, Cassimjee H, Moodley S. Direct admission versus inter-hospital transfer to a level I trauma unit improves survival: An audit of the new Inkosi Albert Luthuli central hospital trauma unit. S Afr Med J. 2011;101:176-8. 53. Garwe T, Cowan LD, Neas BR, Sacra JC, Albrecht RM. Directness of transport of major trauma patients to a level I trauma center: a propensity-adjusted survival analysis of the impact on short-term mortality. J Trauma. 2011;70:1118-27. 
54. Hartl R, Gerber LM, lacono L, Ni Q, Lyons K, Ghajar J. Direct transport within an organized state trauma system reduces mortality in patients with severe traumatic brain injury. J Trauma. 2006;60:1250-6.

55. Helling TS, Davit F, Edwards K. First echelon hospital care before trauma center transfer in a rural trauma system: does it affect outcome? J Trauma. 2010;69:1362-6.

56. Hsiao K, Chen I, Yang C, Hsiao C, Chen K. Is direct transport to a trauma centre best for patients with severe traumatic brain injury? A study in south-central Taiwan. Emerg Med J. 2012;29:156-9.

57. Johnson DL, Krishnamurthy S. Send severely head-injured children to a pediatric trauma center. Pediatr Neurosurg. 1996;25:309-14.

58. Joosse P, Saltzherr T-P, van Lieshout WAM, van Exter P, Ponsen K-J, Vandertop WP, Goslings JC, TraumaNet AMC, collaborating h. Impact of secondary transfer on patients with severe traumatic brain injury. J Trauma Acute Care Surg. 2012;72:487-90.

59. Kejriwal R, Civil I. Time to definitive care for patients with moderate and severe traumatic brain injury--does a trauma system matter? N Z Med J. 2009;122:40-6.

60. Larson JT, Dietrich AM, Abdessalam SF, Werman HA. Effective use of the air ambulance for pediatric trauma. J Trauma. 2004;56:89-93.

61. Nakahara S, Matsuoka T, Ueno M, Mizushima Y, Ichikawa M, Yokota J, Yoshida K. Predictive factors for undertriage among severe blunt trauma patients: what enables them to slip through an established trauma triage protocol? J Trauma. 2010;68:1044-51.

62. Nardi G, Massarutti D, Muzzi R, Kette F, De Monte A, Carnelos GA, Peressutti R, Berlot G, Giordano F, Gullo A. Impact of emergency medical helicopter service on mortality for trauma in north-east Italy. A regional prospective audit. Eur J Emerg Med. 1994;1:69-77. 
63. Nirula R, Maier R, Moore E, Sperry J, Gentilello L. Scoop and run to the trauma center or stay and play at the local hospital: hospital transfer's effect on mortality. J Trauma. 2010;69:595-9.

64. Obremskey W, Henley MB. A comparison of transferred versus direct admission orthopedic trauma patients. J Trauma. 1994;36:373-6.

65. Osterwalder JJ. Could a regional trauma system in eastern Switzerland decrease the mortality of blunt polytrauma patients? A prospective cohort study. J Trauma. 2002;52:1030-6.

66. Poon WS, Li AK. Comparison of management outcome of primary and secondary referred patients with traumatic extradural haematoma in a neurosurgical unit. Injury. $1991 ; 22: 323-5$

67. Rogers FB, Osler TM, Shackford SR, Cohen M, Camp L, Lesage M. Study of the outcome of patients transferred to a level I hospital after stabilization at an outlying hospital in a rural setting. J Trauma. 1999;46:328-33.

68. Sollid S, Munch-Ellingsen J, Gilbert M, Ingebrigtsen T. Pre- and inter-hospital transport of severely head-injured patients in rural Northern Norway. J Neurotrauma. 2003;20:309-14.

69. Stone JL, Lowe RJ, Jonasson O, Baker RJ, Barrett J, Oldershaw JB, Crowell RM, Stein RJ. Acute subdural hematoma: direct admission to a trauma center yields improved results. J Trauma. 1986;26:445-50.

70. Timberlake GA. Blunt pancreatic trauma: experience at a rural referral center. Am Surg. 1997;63:282-6. 
71. Young JS, Bassam D, Cephas GA, Brady WJ, Butler K, Pomphrey M. Interhospital versus direct scene transfer of major trauma patients in a rural trauma system. Am Surg. $1998 ; 64: 88-91$.

72. Cummings G, O'Keefe G. Scene disposition and mode of transport following rural trauma: a prospective cohort study comparing patient costs. J Emerg Med. 2000;18:349-54. 73. Gage AM, Traven N, Rivara FP, Jurkovich GJ, Arbabi S. Compliance with Centers for Disease Control and Prevention field triage guidelines in an established trauma system. J Am Coll Surg. 2012;215:148-54.

74. Falcone RE, Herron $\mathrm{H}$, Werman $\mathrm{H}$, Bonta M. Air medical transport of the injured patient: scene versus referring hospital. Air Med J. 1998;17:161-5.

75. London JA, Rosengart MR, Jurkovich GJ, Nathens AB. Prospective payments in a regional trauma center: the case for recognition of the transfer patient in diagnostic related groups. J Trauma. 2006;60:390-5.

76. Lubin JS, Delbridge TR, Cole JS, Nicholas DH, Fore CA, Wadas RJ. EMS and emergency department physician triage: injury severity in trauma patients transported by helicopter. Prehosp Emerg Care. 2005;9:198-202.

77. Odetola FO, Mann NC, Hansen KW, Patrick S, Bratton SL. Source of admission and outcomes for critically injured children in the mountain states. Arch Pediatr Adolesc Med. 2010;164:277-82.

78. Schwartz RJ, Jacobs LM, Yaezel D. Impact of pre-trauma center care on length of stay and hospital charges. J Trauma. 1989;29:1611-5.

79. Sethi D, Aljunid S, Saperi SB, Clemens F, Hardy P, Elbourne D, Zwi AB, Research Steering C. Comparison of the effectiveness of trauma services provided by secondary and tertiary hospitals in Malaysia. Ann Emerg Med. 2007;49:52-61, .e1. 
80. Spain DA, Bellino M, Kopelman A, Chang J, Park J, Gregg DL, Brundage SI. Requests for 692 transfers to an academic level I trauma center: implications of the emergency medical treatment and active labor act. J Trauma. 2007;62:63-7.

81. VanRooyen MJ, Sloan EP, Barrett JA, Smith RF, Reyes HM. Outcome in an urban pediatric trauma system with unified prehospital emergency medical services care. Prehospital Disaster Med. 1995;10:19-23.

82. de Jongh MAC, Meeuwis JD, van Baar ME, van Stel HF, Schrijvers AJP. Evaluation of trauma care by comparing mortality risks and admission policy in a Dutch trauma region. Injury. 2008;39:1007-12.

83. Helling TS. The challenges of trauma care in the rural setting. 2003;100:510-4.

84. Osterwalder JJ. Insufficient quality of research on prehospital medical emergency care--where are the major problems and solutions? Swiss Med Wkly. 2004;134:389-94.

85. Kidd D, Stewart G, Baldry J, Johnson J, Rossiter D, Petruckevitch A, Thompson AJ. The Functional Independence Measure: a comparative validity and reliability study. Disabil Rehabil. 1995;17:10-4.

86. Langhelle A, Lossius HM, Silfvast T, Bjornsson HM, Lippert FK, Ersson A, Soreide E. International EMS Systems: the Nordic countries. Resuscitation. 2004;61:9-21.

87. Nathens AB, Jurkovich GJ, Cummings P, Rivara FP, Maier RV. The effect of organized systems of trauma care on motor vehicle crash mortality. JAMA. 2000;283:1990-4.

88. Danne PD. Trauma management in Australia and the tyranny of distance. World J Surg. 2003;27:385-9.

89. Fitzgerald G, Tippett V, Schuetz M, Pollard C. The Queensland Trauma Plan project. ANZ J Surg. 2008;78:780-3. 
90. Shafi S, Ahn C, Parks J, Nathens AB, Cryer HM, Gentilello LM, Hemmila M, Fildes JJ. Quality of Care Within a Trauma Center Is not Altered by Injury Type. J Trauma. 2010;68:716-20.

91. Haas B, Jurkovich GJ, Wang J, Rivara FP, Mackenzie EJ, Nathens AB. Survival advantage in trauma centers: expeditious intervention or experience? J Am Coll Surg. $2009 ; 208: 28-36$.

92. Garwe T, Cowan LD, Neas BR, Sacra JC, Albrecht RM, Rich KM. A propensity score analysis of prehospital factors and directness of transport of major trauma patients to a level I trauma center. J Trauma. 2011;70:120-9.

93. Shafi S, Stewart RM, Nathens AB, Friese RS, Frankel H, Gentilello LM. Significant variations in mortality occur at similarly designated trauma centers. Arch Surg. 2009;144:648.

94. Cudnik MT, Sayre MR, Hiestand B, Steinberg SM. Are all trauma centers created equally? A statewide analysis. Acad Emerg Med. 2010;17:701-8.

95. Gomes E, Araujo R, Carneiro A, Dias C, Costa-Pereira A, Lecky FE. The importance of pre-trauma centre treatment of life-threatening events on the mortality of patients transferred with severe trauma. Resuscitation. 2010;81:440-5.

96. Sloan EP, Callahan EP, Duda J, Sheaff CM, Robin AP, Barrett JA. The effect of urban trauma system hospital bypass on prehospital transport times and Level 1 trauma patient survival. Ann Emerg Med. 1989;18:1146-50.

97. Ringdal K, Coats T, Lefering R, Di Bartolomeo S, Steen P, Røise O, Handolin L, Castrén M, Christensen E, Edwards A, Eken T, Gomes E, Hestnes M, Klarin L, Larsen M, Lauritsen J, Leppäniemi A, Örtenwall P, Skaga N, Wisborg T, Woodford M, Lossius H. The Utstein Trauma Template for Uniform Reporting of Data following Major Trauma: Data Dictionary. Version 
1.1.1. European Trauma Registry Network, 2008. Available from

http://scantem.org/misc/pdf/Revised Utstein Template - Data Dictionary v1.1.1.pdf.

FIGURE LEGEND

Figure 1. Flow diagram of study selection

Figure 2. Summary of the unadjusted mortality proportion for studies from USA, Canada, Europe, and Australia and New Zealand comparing the direct transport versus transport to a secondary center than transfer of trauma patients to level I/II trauma centers.

\section{Supplementary Data}

Figure A. Funnel plot to demonstrate presence of publication bias: the vertical axis plots the standard error and the horizontal axis plots the logit event (mortality) rate, defined as logit $(p)=\log (p)-\log (1-p)$, where $p$ is the event (mortality) rate

Figure B. Galbraith plot to assess heterogeneity for the 30 studies evaluated 
Table 1. Health care contexts (at the time study was conducted) of studies that compared direct transport of patients or transport to secondary center then transfer to the Level I/II Trauma Center

\begin{tabular}{|c|c|c|c|}
\hline Study & Study location & Trauma guideline & Trauma system \\
\hline \multicolumn{4}{|l|}{$\begin{array}{l}\text { United } \\
\text { States }\end{array}$} \\
\hline $\begin{array}{l}\text { Garwe et al. } \\
(2011)^{49}\end{array}$ & Oklahoma & $\begin{array}{l}\text { Oklahoma's Trauma System matched patients on a } \\
\text { regional basis with the closest facility with the capability } \\
\text { to provide definitive care for each injury } \\
\text { If necessary, interfacility transfer was coordinated after } \\
\text { initial stabilization taking severity and time-sensitivity of } \\
\text { injury into consideration } \\
\text { Majority of patients in the transfer group (61\%) were } \\
\text { transported from the scene of injury to the initial } \\
\text { hospital by basic life-support service EMS agencies }\end{array}$ & $\begin{array}{l}\text { Mandatory, inclusive trauma system } \\
\text { Single Level I TC, two Level II TCs, } 29 \text { Level III and } 75 \text { IV TCs } \\
\text { (level III \& IV primarily in rural area) }\end{array}$ \\
\hline $\begin{array}{l}\text { Harrington } \\
\text { et al. } \\
(2005)^{17}\end{array}$ & Rhode Island & $\begin{array}{l}\text { Protocols recommended transfer to TC for severely } \\
\text { injured patients if transportation }<20 \text { minutes } \\
\text { Allows for transport to nearest medical facility in } \\
\text { patients injured outside this } 20 \text {-minute radius } \\
\text { Rhode Island currently has } 88 \text { licensed EMS } \\
\text { transportation agencies, a majority of which are based } \\
\text { in fire departments } \\
\text { Approximately } 100 \text { rescue and ambulance squads in the } \\
\text { state }\end{array}$ & $\begin{array}{l}\text { No centralized trauma system } \\
\text { One designated TC serves entire state of Rhode Island, } \\
\text { portions of southeastern Massachusetts and eastern } \\
\text { Connecticut } \\
\text { Has in-house trauma attending and operating room } \\
\text { facilities available within } 5 \text { minutes of patient arrival } \\
24 \text { hospitals transferred patients to TC during study - none } \\
\text { possessed any level of trauma designation } \\
\text { Some had an operating room available on call } 24 \text { hours per } \\
\text { day, while others have no operating room availability in } \\
\text { the evening/night. }\end{array}$ \\
\hline $\begin{array}{l}\text { Hartl et al. } \\
(2006)^{50}\end{array}$ & $\begin{array}{l}\text { New York } \\
\text { State }\end{array}$ & $\begin{array}{l}\text { Patients with severe TBI (GCS score }<9 \text { ) transported } \\
\text { directly to a facility with immediately available } \\
\text { computed tomography }(\mathrm{CT}) \text { scanning, prompt } \\
\text { neurosurgical care, and ability to monitor ICP and treat }\end{array}$ & $\begin{array}{l}46 \text { designated TCs in New York State, two exclusively } \\
\text { paediatric TCs } \\
\text { In 2000, } 5 \text { Level I TCs participating in study } \\
\text { In 2004, } 22 \text { Level I and two Level II participating TCs }\end{array}$ \\
\hline
\end{tabular}




\begin{tabular}{|c|c|c|c|}
\hline & & intracranial hypertension & representing $54 \%$ of the total TCs in the state \\
\hline $\begin{array}{l}\text { Helling et al. } \\
(2010)^{51}\end{array}$ & Pennsylvania & $\begin{array}{l}\text { Patients transported directly to the regional TC } \\
\text { (Conemaugh Memorial Medical Centre), or to nearest } \\
\text { hospital and then transferred }\end{array}$ & $\begin{array}{l}\text { Level I regional resource TC located in Highlands area of } \\
\text { western Pennsylvania, comprising largely rural } \\
\text { communities } \\
\text { No other designated TCs within the primary service area, } \\
\text { closest TC (Level II) located } 50 \text { miles to the east in Altoona, } \\
\text { Pennsylvania, a 60-minute travel distance by vehicle under } \\
\text { normal conditions }\end{array}$ \\
\hline $\begin{array}{l}\text { Johnson } \\
(1996)^{53}\end{array}$ & $\begin{array}{l}\text { Washington } \\
\text { DC }\end{array}$ & Not described & $\begin{array}{l}\text { Neurosurgical service, Level I paediatric TC, adjacent to } \\
\text { level I adult TC. Age of children hospital admits not } \\
\text { specified }\end{array}$ \\
\hline $\begin{array}{l}\text { Larson et al. } \\
(2004)^{56}\end{array}$ & $\begin{array}{l}\text { Central and } \\
\text { south-eastern } \\
\text { Ohio }\end{array}$ & $\begin{array}{l}\text { Most EMS personnel in referral area trained to use } \\
\text { mechanism of injury and physiologic status of the } \\
\text { patient as means of identifying need for rapid transport } \\
\text { to TC } \\
\text { Decision to transfer patient from outlying hospital to } \\
\text { paediatric TC made by medical team at that institution } \\
\text { Helicopter transport between hospitals made by } \\
\text { consultation between referring physician and paediatric } \\
\text { emergency medicine physician at Children's Hospital } \\
\text { who acts as medical control for the air ambulance }\end{array}$ & $\begin{array}{l}\text { Columbus Children's Hospital, ACS-verified Level I } \\
\text { paediatric TC in mixed urban and rural area. Paediatric } \\
\text { patients less than } 19 \text { years of age }\end{array}$ \\
\hline $\begin{array}{l}\text { Nathens et } \\
\text { al. }(2003)^{19}\end{array}$ & $\begin{array}{l}\text { Central region } \\
\text { - King County, } \\
\text { Washington } \\
\text { State }\end{array}$ & $\begin{array}{l}\text { Decision to divert patients from the field directly to } \\
\text { Level I TC made by medical control at closest Level I/II } \\
\text { TC } \\
\text { Advanced Life Support crew carries out virtually all } \\
\text { interfacility transports }\end{array}$ & $\begin{array}{l}8 \text { state-designated TCs: single Level I TC, three Level III TCS, } \\
\text { and four Level IV TCs } \\
\text { Average driving distance between the Level III/IV centres } \\
\text { and Level I facility } 16 \text { miles (range11-24) }\end{array}$ \\
\hline $\begin{array}{l}\text { Nirula et al. } \\
(2010)^{59}\end{array}$ & $\begin{array}{l}\text { Participating } \\
\text { sites included } \\
\text { Washington } \\
\text { State, Seattle; } \\
\text { Dallas, Texas; }\end{array}$ & Not described & $\begin{array}{l}\text { Eight Level I trauma or burn centres participating in the } \\
\text { Inflammation and the Host Response to Injury } \\
\text { collaborative research program }\end{array}$ \\
\hline
\end{tabular}




\begin{tabular}{|c|c|c|c|}
\hline & $\begin{array}{l}\text { Denver, } \\
\text { Colorado; } \\
\text { Pittsburgh }\end{array}$ & & \\
\hline $\begin{array}{l}\text { Obremskey } \\
\text { \& Henley } \\
(1994)^{60}\end{array}$ & $\begin{array}{l}\text { King County, } \\
\text { Washington } \\
\text { State, Seattle }\end{array}$ & $\begin{array}{l}\text { Decision to divert patients from the field directly to } \\
\text { Level I TC made by medical control at closest Level I/II } \\
\text { TC } \\
\text { Advanced Life Support crew carries out virtually all } \\
\text { interfacility transports }\end{array}$ & $\begin{array}{l}\text { Single level I TC (Harborview Medical Centre), three Level } \\
\text { III TCs, and four Level IV TCs }\end{array}$ \\
\hline $\begin{array}{l}\text { Rivara et al. } \\
(2008)^{29}\end{array}$ & $\begin{array}{l}\text { King County, } \\
\text { Washington } \\
\text { State, Seattle }\end{array}$ & Not described & Single level $1 \mathrm{TC}$ \\
\hline $\begin{array}{l}\text { Rogers et al. } \\
(1999)^{63}\end{array}$ & Vermont & $\begin{array}{l}\text { Pre-hospital care provided by volunteer ambulance } \\
\text { attendants with only emergency medical technician } \\
\text { capabilities } \\
\text { No written protocols defining a major trauma patient } \\
\text { nor any protocols governing patient transfers }\end{array}$ & $\begin{array}{l}\text { No formal trauma system } \\
\text { Single level I TC serves rural areas in Vermont and upstate } \\
\text { New York }\end{array}$ \\
\hline $\begin{array}{l}\text { Stone et al. } \\
(1986)^{65}\end{array}$ & Illinois & $\begin{array}{l}\text { Policy for patients to be triaged to nearest } \\
\text { comprehensive ED } \\
\text { Patients transported by ambulance }\end{array}$ & $\begin{array}{l}\text { Illinois developed a state-wide trauma system in the early } \\
\text { 1970s. Cook County trauma unit and community hospitals }\end{array}$ \\
\hline $\begin{array}{l}\text { Timberlake } \\
(1987)^{66}\end{array}$ & $\begin{array}{l}\text { Morgantown, } \\
\text { West Virginia }\end{array}$ & Not described & University hospital designated as Level 1 TC \\
\hline $\begin{array}{l}\text { Young et al. } \\
(1998)^{67}\end{array}$ & $\begin{array}{l}\text { Central and } \\
\text { Western } \\
\text { Virginia }\end{array}$ & $\begin{array}{l}\text { Aeromedical critical care transfer program } \\
\text { Patients referred to TC by road ambulance or } \\
\text { helicopter, directly from scene or via interhospital } \\
\text { transfer }\end{array}$ & $\begin{array}{l}\text { Single TC (The University Virginia Health Science Centre) } \\
\text { Classified rural area because no city }>75,000 \text { people }\end{array}$ \\
\hline \multicolumn{4}{|l|}{ Canada } \\
\hline $\begin{array}{l}\text { Bell et al. } \\
(2012)^{47}\end{array}$ & $\begin{array}{l}\text { British } \\
\text { Columbia }\end{array}$ & $\begin{array}{l}\text { Current transport protocol to designated TCs in BC is } \\
\text { based on a tiered response } \\
\text { Many trauma patients transferred to closest available } \\
\text { medical centre before transfer to regional burn centre }\end{array}$ & $\begin{array}{l}\text { Level I TC supported by supported in rural and remote } \\
\text { areas of the province by local trauma hospitals } \\
\text { In } 2010,3 \text { designated adult level I / II TCs to every } 1 \text { burn } \\
\text { centre }^{86}\end{array}$ \\
\hline
\end{tabular}




\begin{tabular}{|c|c|c|c|}
\hline & & $\begin{array}{l}\text { Transports of severely injured patients organized by the } \\
\text { Ambulance Service and critical care transport team } \\
\text { Ground ambulance for short distances or within urban } \\
\text { areas, helicopters primarily transfer patients over } \\
\text { distances < } 300 \mathrm{~km} \text { and fixed-wing aircraft transport } \\
\text { patients over greater distances } \\
\text { Transport modes depend on time of day and weather }\end{array}$ & \\
\hline $\begin{array}{l}\text { Haas et al. } \\
(2012)^{20}\end{array}$ & Ontario & Not described & $\begin{array}{l}\text { Nine Level I or II adult TCs; all located in major urban areas } \\
\text { No Level III, IV, or V TCs in the region }{ }^{86} \\
\text { Approximately } 150 \text { acute care hospitals that do not } \\
\text { participate in the provincial trauma system and trauma } \\
\text { team not required, trauma transfer protocol, or ED } \\
\text { personnel required to have dedicated training in the } \\
\text { preliminary care of the injured patient (Advanced Trauma } \\
\text { Life Support). }\end{array}$ \\
\hline $\begin{array}{l}\text { Sampalis et } \\
\text { al. }(1997)^{28}\end{array}$ & $\begin{array}{l}\text { Montreal and } \\
\text { Quebec }\end{array}$ & $\begin{array}{l}\text { Policy 1993-1995 - all major trauma patients } \\
\text { transported to nearest ED for stabilisation, then } \\
\text { transferred to level I TC } \\
\text { Pre-hospital services in Canada vary with advanced life } \\
\text { support paramedics in large urban centres, BLS in some } \\
\text { (e.g. Montreal) and others mixed BLS/ALS services }\end{array}$ & $\begin{array}{l}\text { Three-tiered system, tertiary (level I TCs), secondary (level } \\
\text { II TCs, surgical and ED staff with other specialists on-call) } \\
\text { and primary TCs (stabilization centres with ED coverage } \\
\text { and on-call surgeons) } \\
\text { This study, } 3 \text { Level I TCs, } 2 \text { in Montreal and one in Quebec } \\
\text { City }\end{array}$ \\
\hline \multicolumn{4}{|l|}{ Europe } \\
\hline $\begin{array}{l}\text { de Jongh et } \\
\text { al. } 2008^{79}\end{array}$ & $\begin{array}{l}\text { St. Elisabeth } \\
\text { Hospital, } \\
\text { Noord- } \\
\text { Brabant } \\
\text { province, } \\
\text { Netherlands }\end{array}$ & $\begin{array}{l}\text { Policy to transport trauma patients to nearest hospital } \\
\text { and transfer to TC if further treatment required }\end{array}$ & $\begin{array}{l}\text { Single regional level } 1 \text { TC with large neurosurgical unit } \\
15 \text { EDs in the region }\end{array}$ \\
\hline $\begin{array}{l}\text { Joosse et al. } \\
(2012)^{54}\end{array}$ & $\begin{array}{l}\text { Academic } \\
\text { Medical }\end{array}$ & $\begin{array}{l}\text { Decision to transport patient to specialized } \\
\text { neurosurgical trauma care is made on-scene by trained }\end{array}$ & $\begin{array}{l}\text { Three levels: (1) TCs (Level I), (2) large general hospitals } \\
\text { without neurosurgical facilities but capable of treating }\end{array}$ \\
\hline
\end{tabular}




\begin{tabular}{|c|c|c|c|}
\hline & $\begin{array}{l}\text { Centre, } \\
\text { Amsterdam, } \\
\text { Netherlands }\end{array}$ & $\begin{array}{l}\text { ambulance nurses based on several clinical parameters } \\
\text { (e.g. GCS score }<9 \text {, abnormal pupillary reaction) }\end{array}$ & $\begin{array}{l}\text { patients with major trauma (3) hospitals with restricted } \\
\text { capacity for trauma care } \\
\text { University hospital Level I TC and } 12 \text { regional acute care } \\
\text { hospitals categorized according to available facilities to } \\
\text { provide trauma care }\end{array}$ \\
\hline $\begin{array}{l}\text { Moen et al. } \\
(2008)^{16}\end{array}$ & Mid Norway & $\begin{array}{l}\text { Single level } 1 \mathrm{TC} \\
\text { Patients transported from scene of accident by the air } \\
\text { ambulance, decision to transport to local or to } \\
\text { University Hospital made by attending air ambulance } \\
\text { anaesthesiologist } \\
\text { Ground ambulances staffed by paramedics transport } \\
\text { patients to nearest hospital to accident scene }\end{array}$ & $\begin{array}{l}\text { 3-level system of public hospitals in Norway } \\
\text { Mid-Norway there are seven local district general } \\
\text { hospitals, one central hospital and one university hospital } \\
\text { with a neurosurgical department }\end{array}$ \\
\hline $\begin{array}{l}\text { Sollid et al. } \\
(2003)^{64}\end{array}$ & $\begin{array}{l}\text { Three counties } \\
\text { - Nordland, } \\
\text { Troms \& } \\
\text { Finnmark, } \\
\text { Northern } \\
\text { Norway }\end{array}$ & $\begin{array}{l}\text { Aircraft co-ordinated and directed from Air Ambulance } \\
\text { Dispatch Centre located in University Hospital's ED } \\
\text { Inter-hospital transfer between the } 10 \text { hospitals and TC } \\
\text { by fixed wing aircraft staffed with pilots, a specialized } \\
\text { nurse attendant and an anaesthetist when necessary }\end{array}$ & $\begin{array}{l}\text { Single level I TC (University Hospital of North Norway) } \\
\text { Trauma system includes nine district general hospitals, } \\
\text { central hospital in Bodø and level I TC } \\
\text { Advanced air ambulance service provides 24-hour access } \\
\text { to pre- and inter-hospital transport } \\
\text { Fixed-wing aircraft, rotorwing and helicopter air } \\
\text { ambulances }\end{array}$ \\
\hline $\begin{array}{l}\text { Nardi et al. } \\
(1994)^{58}\end{array}$ & $\begin{array}{l}\text { North-east } \\
\text { Italy }\end{array}$ & $\begin{array}{l}\text { Single EMS - controls all ambulances and HEMS } \\
\text { Decision to call HEMS at discretion of ambulance crew } \\
\text { on arrival to scene } \\
\text { Transfer group rescued by EMTs with BLS training, } \\
\text { transported to the nearest level } 1 \text { hospital for } \\
\text { stabilisation and then transferred to TC (level } 2 \\
\text { hospital) } \\
\text { HEMS team experienced trauma care anaesthesiologist } \\
\text { and directly transported to a TC after stabilisation in the } \\
\text { field }\end{array}$ & $\begin{array}{l}12 \text { first level hospitals and } 4 \text { second level institutions } \\
\text { (equivalent to Level I TCs) in } 3 \text { Provinces }\end{array}$ \\
\hline Osterwalder & North Eastern & Emergencies coordinated via hospitals, police, and & Single TC and 10 of 11 regional hospitals in the TC's greater \\
\hline
\end{tabular}




\begin{tabular}{|c|c|c|c|}
\hline $\begin{array}{l}\text { et al. } \\
(2002)^{61}\end{array}$ & Switzerland & $\begin{array}{l}\text { Swiss Rescue Flight Guard } \\
\text { Decision to transfer directly or indirectly to TC for } \\
\text { patients from immediate catchment areas of regional } \\
\text { hospitals depended on different criteria, e.g. type of } \\
\text { alarm service (direct via Rescue Flight Guard, police, or } \\
\text { hospital emergency service), hospital policy (three } \\
\text { hospitals did not usually permit direct admission to TC) } \\
\text { or chance } \\
\text { Ambulance teams generally consisted of two } \\
\text { emergency medical technicians } \\
\text { Emergency medical technicians often accompanied by } \\
\text { an emergency physician, anesthaesiologist, or } \\
\text { anaesthetic nurse with experience in intubation }\end{array}$ & $\begin{array}{l}\text { catchment area } \\
\text { Nearest regional hospital is approximately } 11.7 \mathrm{~km} \text { away } \\
\text { and the farthest is about } 94 \mathrm{~km} \text { away from the TC } \\
\text { Police responsible for emergency services for St. Gallen city } \\
\text { and surrounding area, the site, and the immediate } \\
\text { catchment area of the TC } \\
\text { Regional hospitals responsible for other regions }\end{array}$ \\
\hline \multicolumn{4}{|l|}{ Asia } \\
\hline $\begin{array}{l}\text { Hsiao et al. } \\
(2010)^{52}\end{array}$ & Taiwan & $\begin{array}{l}\text { EMS usually transport patient to the nearest hospital } \\
\text { Bypassing the nearest hospital to another hospital } \\
\text { occurred if requested by the patient or their family } \\
\text { Advanced airway management and intravenous fluid } \\
\text { resuscitation are rarely performed by emergency } \\
\text { medical technicians } \\
\text { Patients transported by EMS usually get oxygen } \\
\text { supplement, immobilisation and BLS as needed }\end{array}$ & $\begin{array}{l}\text { University-affiliated general hospital, similar to level } 1 \text { TC } \\
\text { Rating system for emergency care facilities (including } \\
\text { trauma care) among hospitals began after the period of } \\
\text { this study }\end{array}$ \\
\hline $\begin{array}{l}\text { Kam et al. } \\
(1998)^{37}\end{array}$ & Hong Kong & $\begin{array}{l}\text { Policy to transfer to nearest hospital } \\
10 \% \text { of ambulance crews have higher level of training } \\
\text { e.g. IV fluid therapy, spinal immobilisation }\end{array}$ & $\begin{array}{l}\text { Single general hospital, trauma level I/II } \\
\text { Patients managed by Hospital Trauma Team in 1200-bed } \\
\text { general hospital since formation of Team, August 1994 }\end{array}$ \\
\hline $\begin{array}{l}\text { Nakahara et } \\
\text { al. }(2010)^{57}\end{array}$ & $\begin{array}{l}\text { Southern } \\
\text { Osaka, Japan }\end{array}$ & $\begin{array}{l}12 \text { Fire Departments manage ambulance teams } \\
\text { Small municipalities and adjacent municipalities form } \\
\text { joint Fire Departments } \\
\text { Trauma triage protocol with four-step algorithms, } \\
\text { similar to the ACS protocol, introduced January } 2001\end{array}$ & $\begin{array}{l}\text { Two levels of care described: critical care medical centre, } \\
\text { equivalent to a level I TC, and non-critical care medical } \\
\text { centre hospitals } \\
\text { Catchment area - two medical districts }\end{array}$ \\
\hline
\end{tabular}




\begin{tabular}{|c|c|c|c|}
\hline & & $\begin{array}{l}\text { If criteria for Step I or } 2 \text {, patient transported to critical } \\
\text { care medical centre } \\
\text { If criteria for Step } 3 \text { met, transport to critical care } \\
\text { medical centre or contact on-line medical control } \\
\text { If criteria for Step } 4 \text { met, contact on-line medical control }\end{array}$ & \\
\hline $\begin{array}{l}\text { Poon \& Li } \\
(1991)^{62}\end{array}$ & Hong Kong & $\begin{array}{l}\text { Liberal transfer policy to transfer from general district } \\
\text { hospital to teaching hospital } \\
\text { Referring surgical team provided medical and nursing } \\
\text { escorts for transfers }\end{array}$ & $\begin{array}{l}\text { Teaching hospital with neurosurgical unit. all head injured } \\
\text { patients in ED of TC admitted directly to neurosurgical care } \\
\text { Single district general hospital }\end{array}$ \\
\hline \multicolumn{4}{|c|}{ Australia and New Zealand } \\
\hline $\begin{array}{l}\text { Fatovich et } \\
\text { al. }(2011)^{30}\end{array}$ & $\begin{array}{l}\text { Perth, } \\
\text { Western } \\
\text { Australia }\end{array}$ & $\begin{array}{l}\text { Road transport by single ambulance service provider } \\
\text { Trauma patients transported to appropriate facility as } \\
\text { soon as possible, objective for scene time maximum of } \\
20 \text { minutes, allowing for access and extrication }{ }^{82} \\
\text { Judgement is based on paramedic's assessment of } \\
\text { patients and transport times to the various hospitals }\end{array}$ & $\begin{array}{l}\text { Four tertiary hospitals, one exclusively paediatric, all } \\
\text { located in Perth } \\
\text { Outer ring of six secondary hospitals do not have the } \\
\text { facilities for in-patient management of major trauma } \\
\text { Major trauma patients initially transported to secondary } \\
\text { hospital transferred to tertiary hospital for ongoing and } \\
\text { definitive care }\end{array}$ \\
\hline $\begin{array}{l}\text { Kejriwal \& } \\
\text { Civil }(2009)^{55}\end{array}$ & $\begin{array}{l}\text { Auckland, New } \\
\text { Zealand }\end{array}$ & $\begin{array}{l}\text { Patients with TBI transported to closest regional } \\
\text { hospital for airway, breathing and circulation } \\
\text { assessment and stabilisation }\end{array}$ & $\begin{array}{l}\text { Trauma care in New Zealand delivered in ad hoc trauma } \\
\text { system }\end{array}$ \\
\hline \multicolumn{4}{|l|}{ South Africa } \\
\hline $\begin{array}{l}\text { Cheddie et } \\
\text { al. }(2011)^{48}\end{array}$ & $\begin{array}{l}\text { Durban, South } \\
\text { Africa }\end{array}$ & $\begin{array}{l}\text { Admissions direct from scene in consultation with pre- } \\
\text { hospital care providers or by inter-hospital transfer } \\
\text { Organised, statutory system of pre-hospital care }\end{array}$ & $\begin{array}{l}\text { Single level I trauma unit and trauma ICU, Inkosi Albert } \\
\text { Luthuli Central Hospital based on ACSCOT } 1993 \text { guidelines }^{8} \\
\text { Four level II registrar-based facilities }\end{array}$ \\
\hline \multicolumn{4}{|c|}{ American College of Surgeons } \\
\hline \multicolumn{4}{|c|}{ ALS Advanced life Support } \\
\hline \multicolumn{4}{|c|}{ ACSOTT American College of Surgeons Outcomes of trauma } \\
\hline \multicolumn{4}{|c|}{ BLS Basic Life Support } \\
\hline \multicolumn{4}{|c|}{ Computed tomogr } \\
\hline \multicolumn{4}{|c|}{ Emergency Department } \\
\hline
\end{tabular}


HEMS Helicopter Emergency Medical Services

IV intravenous

Trauma Center

TBI Traumatic Brain Injury 
Figure 1. Flow diagram of study selection

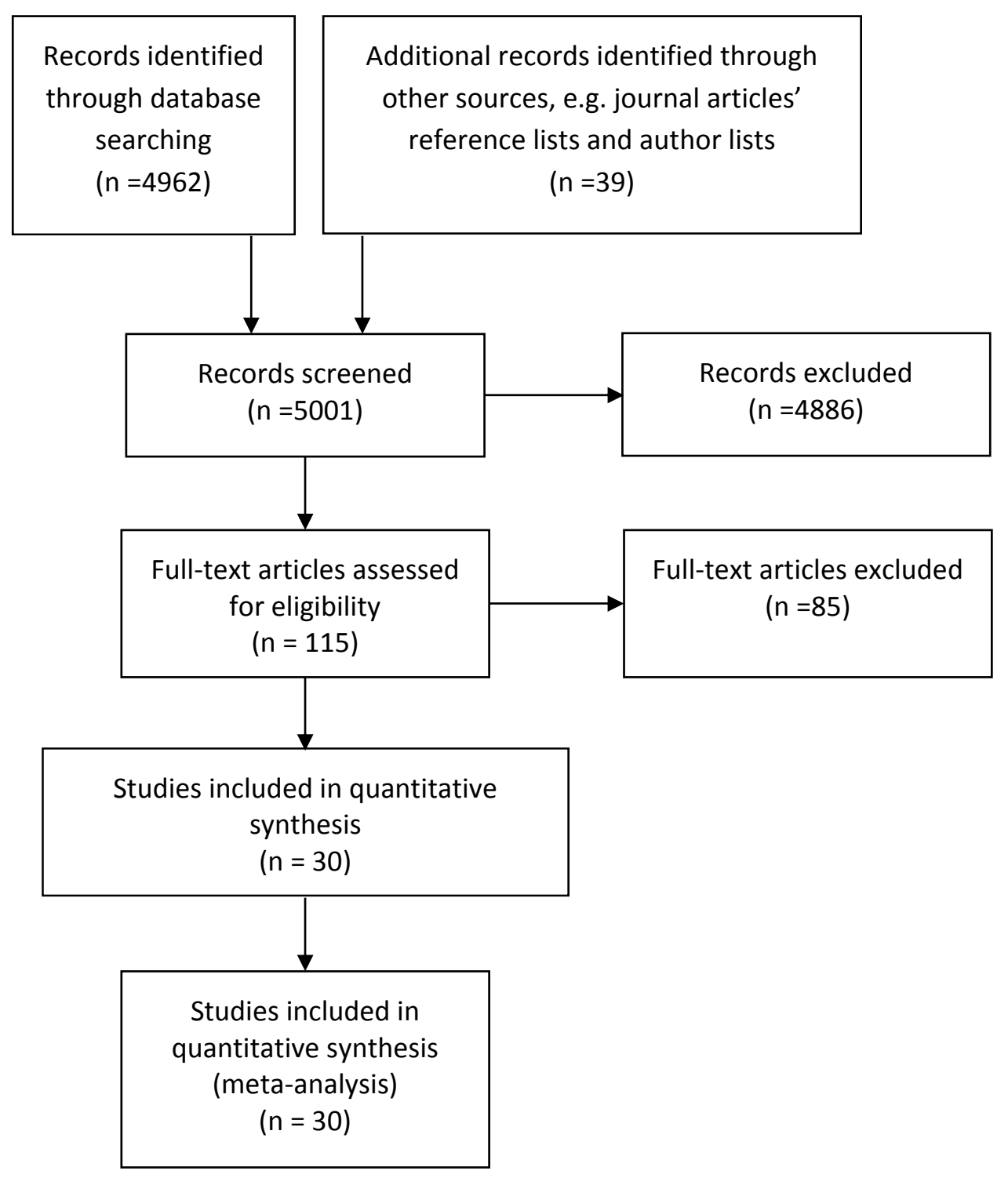


Figure 2. Summary of the unadjusted mortality proportion for studies from USA, Canada, Europe, and Australia and New Zealand comparing the direct versus indirect transport of trauma patients to level I/II trauma centres.

\begin{tabular}{|c|c|c|c|c|c|c|c|}
\hline \multicolumn{8}{|c|}{ 2a Studies conducted in the United States of America } \\
\hline \multirow[b]{2}{*}{ Study or Subgroup } & \multicolumn{2}{|c|}{ Transfer } & \multicolumn{2}{|c|}{ Direct } & \multirow[b]{2}{*}{ Weight } & \multirow{2}{*}{$\begin{array}{c}\text { Odds Ratio } \\
\text { M-H, Random, } 95 \% \mathrm{Cl}\end{array}$} & \multirow{2}{*}{$\begin{array}{c}\text { Odds Ratio } \\
\mathrm{M}-\mathrm{H}, \text { Random, } 95 \% \mathrm{Cl}\end{array}$} \\
\hline & Events & Total & Events & Total & & & \\
\hline Garwe & 63 & 600 & 125 & 1398 & $9.9 \%$ & $1.19[0.87,1.64]$ & - \\
\hline Harrington & 28 & 280 & 237 & 3227 & $8.6 \%$ & $1.40[0.93,2.12]$ & $\leftarrow$ \\
\hline Hartl & 65 & 254 & 179 & 864 & $9.8 \%$ & $1.32[0.95,1.82]$ & $t=-$ \\
\hline Helling & 29 & 267 & 189 & 1209 & $8.5 \%$ & $0.66[0.43,1.00]$ & \\
\hline Johnson & 21 & 42 & 15 & 56 & $4.2 \%$ & $2.73[1.17,6.37]$ & \\
\hline Larson & 43 & 278 & 32 & 120 & $7.2 \%$ & $0.50[0.30,0.85]$ & \\
\hline Nathens & 14 & 281 & 439 & 4439 & $6.9 \%$ & $0.48[0.28,0.83]$ & \\
\hline Nirula & 38 & 315 & 94 & 787 & $8.7 \%$ & $1.01[0.68,1.51]$ & - \\
\hline Obremskey & 6 & 129 & 17 & 384 & $3.5 \%$ & $1.05[0.41,2.73]$ & \\
\hline Rivara & 239 & 2779 & 621 & 7570 & $12.0 \%$ & $1.05[0.90,1.23]$ & 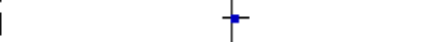 \\
\hline Rogers & 40 & 1061 & 53 & 1608 & $8.5 \%$ & $1.15[0.76,1.75]$ & \\
\hline Stone & 35 & 46 & 41 & 82 & $4.4 \%$ & $3.18[1.42,7.11]$ & \\
\hline Timberlake & 2 & 11 & 2 & 28 & $0.9 \%$ & $2.89[0.35,23.63]$ & \\
\hline Young & 28 & 151 & 38 & 165 & $6.8 \%$ & $0.76[0.44,1.32]$ & 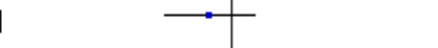 \\
\hline Total $(95 \% \mathrm{Cl})$ & & 6494 & & 21937 & $100.0 \%$ & $1.04[0.85,1.29]$ & \\
\hline Total events & 651 & & 2082 & & & & \\
\hline $\begin{array}{l}\text { Heterogeneity: } \mathrm{Tau}^{2} \\
\text { Test for overall effect }\end{array}$ & $\begin{array}{l}0.09 ; \mathrm{Chi}^{2} \\
\mathrm{Z}=0.40(\end{array}$ & $\begin{array}{l}z=39.6 \\
P=0.6\end{array}$ & $\begin{array}{l}\text { 63, } d f=1 \\
69)\end{array}$ & $3(P=0$ & $0.0002) ; 1^{2}=$ & $=67 \%$ & $\begin{array}{ccccccc} & 1 & 1 & 1 & 1 & 1 \\
0.1 & 0.2 & 0.5 & 1 & 2 & 5 & 10 \\
\text { Favours Transfer } & \text { Favours Direct }\end{array}$ \\
\hline \multicolumn{8}{|c|}{ 2b Studies conducted in Canada } \\
\hline & \multicolumn{2}{|c|}{ Transfer } & \multicolumn{2}{|c|}{ Direct } & \multicolumn{2}{|r|}{ Odds Ratio } & \multirow{2}{*}{$\begin{array}{c}\text { Odds Ratio } \\
\text { M-H, Random, } 95 \% \mathrm{Cl}\end{array}$} \\
\hline Study or Subgroup & Events & Total & Events & Total & Weight & M-H, Random, $95 \% \mathrm{Cl}$ & \\
\hline Bell & 18 & 104 & 15 & 60 & $24.5 \%$ & $0.63[0.29,1.36]$ & \begin{tabular}{l|l}
$\longrightarrow$ & -1
\end{tabular} \\
\hline Haas & 413 & 2003 & 761 & 2857 & $39.0 \%$ & $0.72[0.62,0.82]$ & - \\
\hline Sampalis & 89 & 1608 & 99 & 2756 & $36.5 \%$ & $1.57[1.17,2.11]$ & $\rightarrow-$ \\
\hline Total $(95 \% \mathrm{Cl})$ & & 3715 & & 5673 & $100.0 \%$ & $0.92[0.50,1.72]$ & \\
\hline Total events & 520 & & 875 & & & & \\
\hline $\begin{array}{l}\text { Heterogeneity: } \mathrm{Tau}^{2}= \\
\text { Test for overall effect }\end{array}$ & $\begin{array}{l}0.25 ; \mathrm{Chi}^{2} \\
\mathrm{Z}=0.25\end{array}$ & $\begin{array}{l}z=23.2 \\
P=0.8\end{array}$ & $\begin{array}{l}25, d f=2 \\
30)\end{array}$ & $(\mathrm{P}<0.0$ & $00001) ; 1^{2}=$ & $=91 \%$ & $\begin{array}{lllllll}1 & 1 & 1 & 1 & 1 & 1 \\
0.1 & 0.2 & 0.5 & 1 & 2 & 5 & 10 \\
\text { Favours Transfer } & \text { Favours Direct }\end{array}$ \\
\hline \multicolumn{8}{|c|}{ 2c Studies conducted in Europe } \\
\hline & \multicolumn{2}{|c|}{ Transfer } & \multicolumn{2}{|c|}{ Direct } & & Odds Ratio & \multirow{2}{*}{$\begin{array}{c}\text { Odds Ratio } \\
\text { M-H, Random, } 95 \% \mathrm{Cl}\end{array}$} \\
\hline Study or Subgroup & Events & Total & Events & Total & Weight & M-H, Random, $95 \% \mathrm{Cl}$ & \\
\hline de Jongh & 15 & 69 & 110 & 382 & $20.9 \%$ & $0.69[0.37,1.27]$ & $\longrightarrow+$ \\
\hline Joose & 8 & 24 & 15 & 56 & $9.7 \%$ & $1.37[0.49,3.85]$ & \\
\hline Moen & 9 & 63 & 23 & 83 & $13.2 \%$ & $0.43[0.19,1.02]$ & \\
\hline Nardi & 31 & 82 & 31 & 98 & $20.8 \%$ & $1.31[0.71,2.43]$ & $=$ \\
\hline Osterwalder & 27 & 190 & 33 & 280 & $24.1 \%$ & $1.24[0.72,2.14]$ & $=$ \\
\hline Sollid & 10 & 38 & 16 & 47 & $11.3 \%$ & $0.69[0.27,1.77]$ & - \\
\hline Total $(95 \% \mathrm{Cl})$ & & 466 & & 946 & $100.0 \%$ & $0.91[0.64,1.30]$ & \\
\hline \multirow{2}{*}{\multicolumn{7}{|c|}{$\begin{array}{l}\text { Total events } \quad 100 \quad 228 \\
\text { Heterogeneity: } \text { Tau }^{2}=0.06 ; \mathrm{Chi}^{2}=7.17, \mathrm{df}=5(\mathrm{P}=0.21) ; \mathrm{I}^{2}=30 \% \\
\text { Test for overall effect: } \mathrm{Z}=0.50(\mathrm{P}=0.61)\end{array}$}} & \\
\hline & & & & & & & 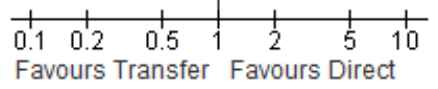 \\
\hline
\end{tabular}




\begin{tabular}{|c|c|c|c|c|c|c|c|}
\hline Study or Subgroup & $\begin{array}{l}\text { Transt } \\
\text { Events }\end{array}$ & $\begin{array}{l}\text { fer } \\
\text { Total }\end{array}$ & $\begin{array}{l}\text { Direc } \\
\text { Events }\end{array}$ & Total & Weight & $\begin{array}{c}\text { Odds Ratio } \\
\text { M-H, Random, } 95 \% \mathrm{Cl}\end{array}$ & $\begin{array}{c}\text { Odds Ratio } \\
\text { M-H, Random, } 95 \% \mathrm{Cl}\end{array}$ \\
\hline Hsiao & 86 & 167 & 55 & 87 & $59.0 \%$ & $0.62[0.36,1.05]$ & $\square$ \\
\hline Kam & 14 & 27 & 21 & 43 & $18.0 \%$ & $1.13[0.43,2.96]$ & \\
\hline Nakahara & 7 & 53 & 49 & 343 & $23.0 \%$ & $0.91[0.39,2.14]$ & \\
\hline Poon & 8 & 33 & 1 & 71 & $0.0 \%$ & $22.40[2.67,188.20]$ & \\
\hline Total $(95 \% \mathrm{Cl})$ & & 247 & & 473 & $100.0 \%$ & $0.75[0.50,1.13]$ & \\
\hline Total events & 107 & & 125 & & & & \\
\hline $\begin{array}{l}\text { Heterogeneity: Tau }{ }^{2}= \\
\text { Test for overall effect: }\end{array}$ & $\begin{array}{l}0.00 ; \mathrm{Chi} \\
Z=1.36(\end{array}$ & $\begin{array}{l}i^{2}=1.41 \\
(P=0.1\end{array}$ & $\begin{array}{l}1, d f=2(F \\
7)\end{array}$ & $P=0.49$ & 9); $\left.\right|^{2}=0 \%$ & & $\begin{array}{ccccccc}1 & 1 & 1 & 1 & 1 & 1 & 1 \\
0.1 & 0.2 & 0.5 & 1 & 2 & 5 & 10 \\
\text { Favours Transfer } & \text { Favours Direct }\end{array}$ \\
\hline \multicolumn{8}{|c|}{ 2e Studies conducted in Australia and New Zealand } \\
\hline \multirow[b]{2}{*}{ Study or Subgroup } & \multicolumn{2}{|c|}{ Transfer } & \multicolumn{2}{|c|}{ Direct } & \multirow{2}{*}{\multicolumn{2}{|c|}{$\begin{array}{c}\text { Odds Ratio } \\
\text { Weight } \mathrm{M-H}, \text { Random, } 95 \% \mathrm{Cl}\end{array}$}} & \multirow{2}{*}{$\begin{array}{c}\text { Odds Ratio } \\
\mathrm{M}-\mathrm{H}, \text { Random, } 95 \% \mathrm{Cl}\end{array}$} \\
\hline & Events & Total & Events & Total & & & \\
\hline Fatovich & 140 & 1078 & 394 & 2005 & $95.3 \%$ & $0.61[0.50,0.75]$ & \\
\hline Kejriwal & 7 & 73 & 17 & 97 & $4.7 \%$ & $0.50[0.20,1.28]$ & \\
\hline Total $(95 \% \mathrm{Cl})$ & & 1151 & & 2102 & $100.0 \%$ & $0.60[0.49,0.74]$ & \\
\hline Total events & 147 & & 411 & & & & \\
\hline \multicolumn{7}{|c|}{$\begin{array}{l}\text { Heterogeneity: } \text { Tau }^{2}=0.00 ; \mathrm{Chi}^{2}=0.17, \mathrm{df}=1(\mathrm{P}=0.68) ; \mathrm{I}^{2}=0 \% \\
\text { Test for overall effect: } Z=4.84(P<0.00001)\end{array}$} & 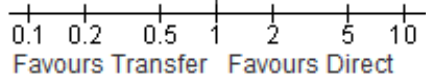 \\
\hline
\end{tabular}


Table A. Comparison of cohort characteristics of direct admissions compared to those transported initially to a secondary hospital and subsequently transferred to level I/II trauma centre for patients with severe trauma

\begin{tabular}{|c|c|c|c|c|c|}
\hline Study & Design & Participants & Group characteristics & $\begin{array}{c}\text { Unadjusted mortality } \\
\text { number of deaths (\%)*and } \\
\text { other patient outcomes } \\
\text { Direct vs transfer }\end{array}$ & Adjusted mortality \\
\hline \multicolumn{6}{|l|}{$\begin{array}{l}\text { United States of } \\
\text { America }\end{array}$} \\
\hline $\begin{array}{l}\text { Garwe et al., } 2011^{49} \\
\text { January } 2006 \text { - } \\
\text { December } 2007\end{array}$ & $\begin{array}{l}\text { Retrospective cohort study, } \\
\text { State Trauma Registry data } \\
\text { Linked data (10 cases } \\
\text { missing) supplemented by } \\
\text { manual record review } \\
\text { Ethics approval }\end{array}$ & $\begin{array}{l}\text { 1,998 patients with major } \\
\text { trauma } \\
\text { Direct group 1,398 (70\%) } \\
\text { patients } \\
\text { Transfer group } 600 \text { (30\%) } \\
\text { patients } \\
\text { Include if transported alive by } \\
\text { EMS to the closest trauma } \\
\text { facility or Level I TC; arrived } \\
\text { at the Level I TC vithin } 24 \\
\text { hours of injury; and } \\
\text { transferred patients only } \\
\text { stopped at one intermediate } \\
\text { facility before subsequent } \\
\text { transfer to the Level I TC } \\
\text { Non-fatal injuries included if } \\
\text { patient hospitalised for } 2+ \\
\text { days at Level I TC } \\
\text { Excluded: patients whose } \\
\text { closest facility a Level I TC, } \\
\text { burn-related injuries, dying in } \\
\text { ED within } 2 \text { hours ( } \mathrm{n}=64 \text { ) of } \\
\text { injury } \\
\text { Missing information from } 23 \\
\text { natients - excluided from }\end{array}$ & $\begin{array}{l}\text { Direct group significantly } \\
\text { more likely to be Black, to } \\
\text { have penetrating injuries, to } \\
\text { be injured during night hours } \\
\text { and to be closer to the Level I } \\
\text { TC } \\
\text { Direct group also transported } \\
\text { from scene of injury by } \\
\text { advanced life support level } \\
\text { EMS provider } \\
\text { Transport group - } \\
\text { disproportionate number of } \\
\text { paediatric and elderly } \\
\text { patients, tendency toward } \\
\text { higher ISS scores and } \\
\text { disproportionate number of } \\
\text { patients vith more severe } \\
\text { (AS score 3) head injuries in } \\
\text { transfer group }\end{array}$ & $\begin{array}{l}24 \text { hour } \\
62 \text { (4.4\%) vs } 21 \text { (3.5\%) } \\
\text { 2-week } \\
115(8.2 \%) \text { vs } 54(9.0 \%) \\
30 \text {-day mortality } \\
\text { 125(9\%) vs } 63 \text { (10.5\%) } \\
\text { Median ICU LOS both } 4 \text { days } \\
\text { Hospital LOS } 6 \text { vs } 7 \text { days }\end{array}$ & $\begin{array}{l}24 \text { hour mortality (HR, 1.7; } \\
\text { 95\% Cl 0.6-4.8) direct vs } \\
\text { transfer cohort } \\
>2 \text { week-30 day-mortality (OR } \\
\text { HR, 2.9; 95\% Cl, 1.3-5.6) } \\
\text { direct vs transfer cohort } \\
>14 \text { day to } 30 \text {-day mortality } \\
\text { (HR, 2.9; 95\% Cl, 0.7-12) } \\
\text { direct vs transfer cohort } \\
\text { Adjusted for propensity to be } \\
\text { transported directly, age, } \\
\text { injury severity score, severe } \\
\text { head injury, emergency } \\
\text { medical senvice or ED } \\
\text { intubation, comorbid } \\
\text { conditions, and time to } \\
\text { definitive Level I trauma care }\end{array}$ \\
\hline
\end{tabular}


mortality multivariable

analyses, none of these died

Data imputed for 70 patients

missing initial scene SBP and

for 39 missing initial scene

GCS score

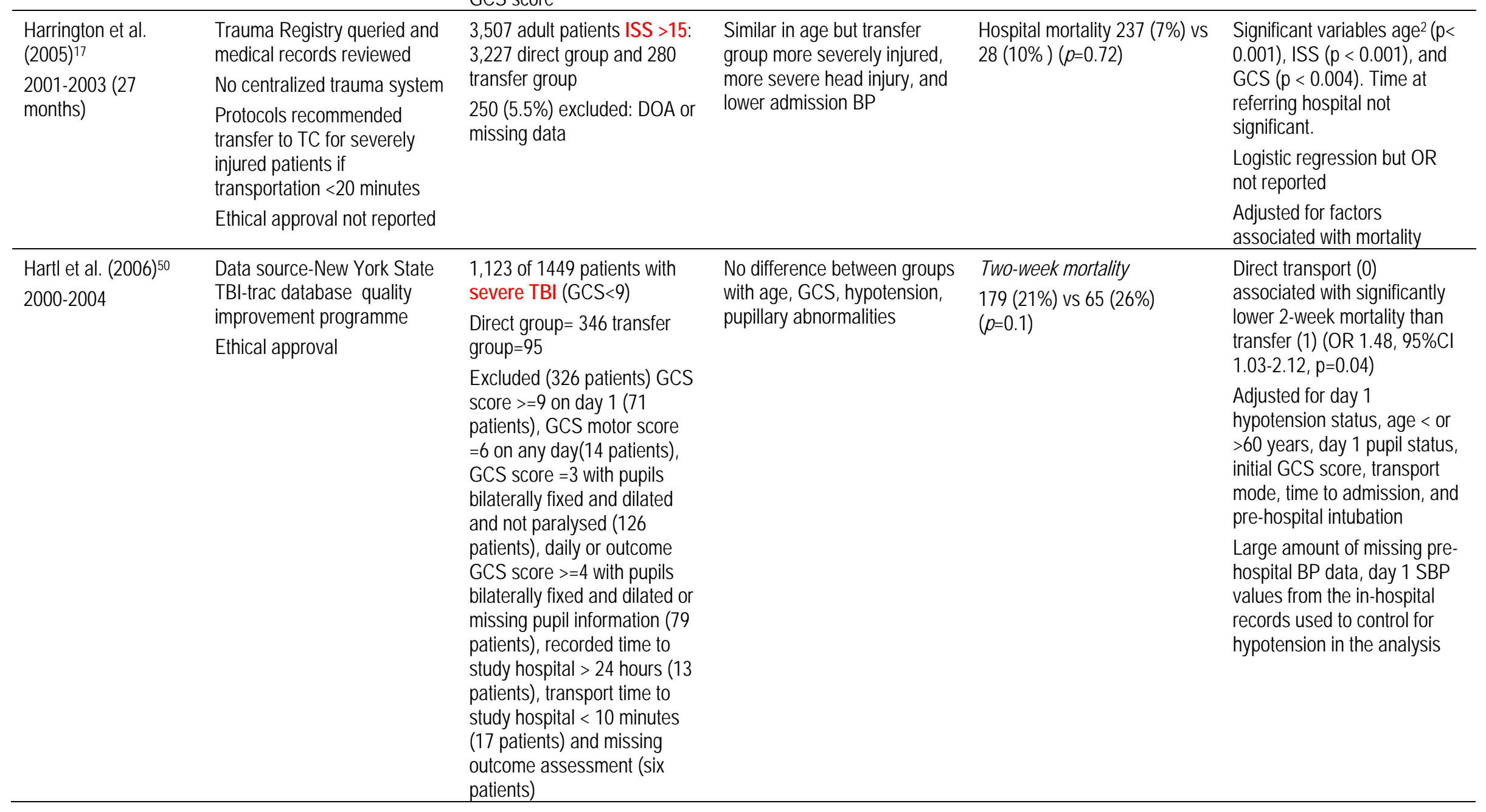




\begin{tabular}{|c|c|c|c|c|c|}
\hline & & $\begin{array}{l}\text { ED not included } \\
\text { Road transport } 46 \% \text {, } \\
\text { helicopter 36\%, private } \\
\text { vehicle } 18 \% \\
\end{array}$ & $\begin{array}{l}\text { assault but higher proportion } \\
\text { abuse and 'other' group }\end{array}$ & & \\
\hline $\begin{array}{l}\text { Larson et al. (2004) }{ }^{56} \\
\text { January 1991-June } \\
1999\end{array}$ & $\begin{array}{l}\text { Retrospective analysis of } \\
\text { trauma registry data } \\
\text { Ethics approval }\end{array}$ & $\begin{array}{l}\text { Pediatric trauma patients } \\
\text { ( }<19 \text { years of age) } \\
\text { transported by helicopter, } \\
\text { admitted to pediatric trauma } \\
\text { center } \\
\text { Included patients who } \\
\text { suffered blunt or penetrating } \\
\text { trauma } \\
1,412 \text { patients transported to } \\
\text { trauma center by helicopter } \\
\text { Excluded burns }(n=99), \\
\text { hanging }(n=7) \text {, drowning ( } n \\
=17), 19+\text { years }(n=5) \text {, } \\
\text { missing ISS }(n=63) \\
\text { Direct group }=379 \text { patients } \\
\text { Transfer group after } \\
\text { stabilisation }=842 \text { patients } \\
\text { Major (ISS }>15) \text { trauma } \\
\text { direct group=120 and transfer } \\
\text { group } 278 \text { patients }\end{array}$ & $\begin{array}{l}\text { Mean age, median ISS, and } \\
\text { distribution of penetrating and } \\
\text { blunt injuries did not differ } \\
\text { significantly between the } \\
\text { groups } \\
\text { Transfer group sustained } \\
\text { fewer injuries from MNAs, } \\
\text { pedestrian versus MNA and } \\
\text { more injuries from assaults, } \\
\text { falls, and sports }\end{array}$ & $\begin{array}{l}\text { Mortality direct group } 33(9 \%) \\
\text { vs } 46(6 \%) \text { for transfer } \\
\text { patients; } p<0.05 \\
\text { For major trauma, direct } 32 \\
(27 \%) \text { vs } 43(16 \%, p<0.05) \\
\text { for transfer group } \\
\text { Direct patients with major } \\
\text { trauma longer mean ICU LOS } \\
149 \text { hours vs } 118 \text { hours; } p< \\
\text { 0.05) for transfer group }\end{array}$ & $\begin{array}{l}\text { No multivariate adjustment for } \\
\text { potential confounders }\end{array}$ \\
\hline $\begin{array}{l}\text { Nathens et al. } \\
(2003)^{19} \\
1995-1998\end{array}$ & $\begin{array}{l}\text { Retrospective study, Trauma } \\
\text { Registry review } \\
\text { Ethics approval not reported }\end{array}$ & $\begin{array}{l}\text { Direct group } 4,439 \text { patients, } \\
\text { transfer group } 281 \text { patients } \\
\text { from urban setting } \\
\text { Trauma patients aged >=16, } \\
\text { LOS }>2 \text { days } \\
\text { Excluded burns }\end{array}$ & $\begin{array}{l}\text { Transfer group similar age } \\
\text { and sex but significantly more } \\
\text { likely to be commercially } \\
\text { insured, healthier and have } \\
\text { blunt injuries. Also lower ISS, } \\
\text { fewer patients with maximum } \\
\text { AIS scores in the highest } \\
\text { strata and TBI less severe }\end{array}$ & $\begin{array}{l}439 \text { (10\%) vs } 14 \text { (5\%) } \\
\text { (RR 0.50; 95\% Cl, 0.30-0.86) }\end{array}$ & $\begin{array}{l}\text { RR of death transfer vs direct } \\
\text { group (RR 1.05; 95\% Cl } \\
\text { O.61-1.80) } \\
\text { Adjusted for age, gender, } \\
\text { insurance status, comorbidity } \\
\text { (cirrhosis, cardiovascular or } \\
\text { cerebrovascular disease, } \\
\text { COPD), mechanism of injury, } \\
\text { ISS, severity of head injury } \\
\text { (head AIS score), maximum } \\
\text { AIS shock (SBP< } 90 \text { mm Hg) } \\
\text { in ED of either the referring }\end{array}$ \\
\hline
\end{tabular}




\begin{tabular}{|c|c|c|c|c|c|}
\hline & & & & & hospital or Level I facility. \\
\hline $\begin{array}{l}\text { Nirula et al. (2010)59 } \\
\text { April } 2004 \text { - June } \\
2007\end{array}$ & $\begin{array}{l}\text { Secondary analysis Glue } \\
\text { Grant Trauma Database - } \\
\text { ongoing large multicentre } \\
\text { prospective cohort study to } \\
\text { evaluate inflammatory } \\
\text { response to injury and } \\
\text { posttraumatic multiple organ } \\
\text { failure } \\
\text { Patients admitted to any } 1 \text { of } \\
8 \text { participating institutions in } \\
\text { United States } \\
\text { Ethics approval not reported }\end{array}$ & $\begin{array}{l}787 \text { patients in the direct } \\
\text { group and } 318 \text { in the transfer } \\
\text { group } \\
\text { Patients aged } 16+\text { years, } \\
\text { blunt trauma, arrival to } \\
\text { hospital within } 6 \text { hours of } \\
\text { injury, hypotension (SBP<90) } \\
\text { or elevated base deficit }>=6 \text { ), } \\
\text { blood transfusion within } 12 \\
\text { hours of injury, body region } \\
\text { with an AIS score }>=2 \\
\text { (excluded brain) and intact } \\
\text { cervical spinal cord } \\
\text { Excluded } 91 \text { (8\%) patients } \\
\text { who died within } 24 \text { hours of } \\
\text { injury }\end{array}$ & $\begin{array}{l}\text { Similar injury mechanisms, } \\
\text { identical ISS, and similar } \\
\text { APACHE II scores, but } \\
\text { transfer group older, greater } \\
\text { proportion of Caucasians, } \\
\text { higher frequency of cardiac } \\
\text { disease }\end{array}$ & $12 \%$ both groups & $\begin{array}{l}\text { Mortality increased for } \\
\text { transfer group (OR 3.0, 95\% } \\
\text { Cl 1.6-9.0) } \\
\text { Adjusted for patient } \\
\text { demographics, time from } \\
\text { injury to TC, resuscitation } \\
\text { volume, transfusions, TBI, } \\
\text { initial SBP, comorbidities and } \\
\text { injury severity }\end{array}$ \\
\hline $\begin{array}{l}\text { Obremskey \& Henley } \\
\text { (1994) }^{60} \\
\text { Jan-Jun } 1990 \text { (6 } \\
\text { months) }\end{array}$ & $\begin{array}{l}\text { Prospective study, trauma } \\
\text { registry data } \\
\text { Subgroup case control study } \\
\text { Ethics approval not reported }\end{array}$ & $\begin{array}{l}513 \text { trauma patients with } \\
\text { musculoskeletal injury } \\
\text { included in ISS and aged >12 } \\
\text { years } \\
384 \text { direct group (admitted } \\
\text { through ED), } 129 \text { transfer } \\
\text { group (admitted from another } \\
\text { hospital) }\end{array}$ & $\begin{array}{l}\text { Similar injuries but significant } \\
\text { differences in ISS, ICU LOS, } \\
\text { total charges } \\
\text { Transfer group higher ISS, no } \\
\text { differences in RTS }\end{array}$ & $\begin{array}{l}17(4.4 \%) \text { vs (6) } 4.7 \% \\
(p=0.89)\end{array}$ & $\begin{array}{l}\text { No multivariate adjustment for } \\
\text { potential confounders for } \\
\text { mortality outcome } \\
103 \text { transfer patients and } 103 \\
\text { controls from direct group } \\
\text { matched on ISS and age, if } \\
>=50 \text { years statistically } \\
\text { significant increase in LOS, } \\
\text { reimbursement, and charges }\end{array}$ \\
\hline $\begin{array}{l}\text { Rivara et al. (2008)29 } \\
1999\end{array}$ & $\begin{array}{l}\text { Retrospective analysis of } \\
\text { data for one participating site } \\
\text { of National Study on Cost and } \\
\text { Outcome of Trauma (NSCOT) } \\
\text { database }{ }^{23} \text { prospective study } \\
\text { of injured patients treated in } 1 \\
\text { of } 18 \text { TCs and } 51 \text { large non- } \\
\text { TCs } \\
\text { Ethics approval }\end{array}$ & $\begin{array}{l}\text { Patients with major trauma, } \\
\text { ISS }>15,18 \text { - } 84 \text { years with at } \\
\text { least one AIS score }>=3 \text { injury } \\
\text { Excluded if first presented for } \\
\text { care }>24 \text { hours after injury or } \\
89 \text { patients admitted to } \\
\text { secondary hospital prior to } \\
\text { transfer to TC } \\
\text { Direct group } 7,570 \text { patients } \\
\text { Transfer group } 2,779\end{array}$ & $\begin{array}{l}\text { No difference in proportion of } \\
\text { males, NISS, but direct group } \\
\text { younger, more likely to have } \\
\text { penetrating injury, and fewer } \\
\text { comorbid conditions }\end{array}$ & $\begin{array}{l}\text { Hospital mortality } \\
621(8.2 \%) \text { vs } 239(8.6 \%)(p= \\
0.66) \\
12-\text { month mortality } \\
10 \% \text { vs } 11 \%(p=0.29)\end{array}$ & $\begin{array}{l}\text { No increase in the adjusted } \\
\text { risk of death w/in } 1 \text { year for } \\
\text { transfer patients (HR 0.99, } \\
95 \% \mathrm{Cl} 0.8,1.3 \text { ) } \\
\text { Adjusted risk of death higher } \\
\text { in transfer patients than direct } \\
\text { group between } 50 \text { days and } \\
365 \text { days after injury (HR } 1.3 \text {, } \\
95 \% \mathrm{Cl} 0.8,2.1 \text { ), but not } \\
\text { within first } 50 \text { days (HR } 0.95 \text {, } \\
95 \% \mathrm{Cl} 0.8,1.2 \text { ) but not }\end{array}$ \\
\hline
\end{tabular}




\begin{tabular}{|c|c|c|c|c|c|}
\hline & & & & & $\begin{array}{l}\text { statistically significant } \\
\text { Adjusted for age group, } \\
\text { gender, injury severity, injury } \\
\text { mechanism, and } \\
\text { comorbidities }\end{array}$ \\
\hline $\begin{array}{l}\text { Rogers et al. (1999)63 } \\
\text { Jan 1993- Jul } 1996 \\
\text { (3.5 years) }\end{array}$ & $\begin{array}{l}\text { Trauma registry data } \\
\text { Most transfers by ground } \\
\text { (94\%) with few (6\%) } \\
\text { transferred by helicopter } \\
\text { Ethics approval not reported }\end{array}$ & $\begin{array}{l}\text { 2,674 trauma patients: } \\
\text { Age not specified } \\
\text { Direct group 1,608 (61\%) } \\
\text { Transfer group 1,061 (39\%) }\end{array}$ & $\begin{array}{l}\text { Transfer group higher injury } \\
\text { severity and acuity, more } \\
\text { head/neck and multiple } \\
\text { injuries }\end{array}$ & $53(3 \%)$ vs 40 (4\%) & $\begin{array}{l}\text { ISS and age contributed } \\
\text { significantly }(p<0.001) \text { to } \\
\text { mortality but transfer }(0) \text { vs } \\
\text { direct group }(1)(O R 0.84, \\
95 \% C l 0.46-1.50, p=0.55) \\
\text { Adjusted for age, ISS transfer } \\
\text { group and RTS }\end{array}$ \\
\hline $\begin{array}{l}\text { Stone et al. }(1986)^{65} \\
\text { 1969-1981 (12 1/2- } \\
\text { years) }\end{array}$ & $\begin{array}{l}\text { Clinical, operation and } \\
\text { autopsy record review } \\
\text { Transported to hospital by } \\
\text { ambulance } \\
\text { Ethics approval not reported }\end{array}$ & $\begin{array}{l}128 \text { patients admitted with } \\
\text { acute SDH } \\
\text { Excluded haematomas } \\
\text { complicating open depressed } \\
\text { fractured skull, gunshot } \\
\text { wound } \\
\text { Male } 91 \% \text { included children. } \\
\text { Assault (58\%), falls (34\%) } \\
\text { Direct group=82 patients } \\
\text { Transfer group= } 46 \text { patients }\end{array}$ & $\begin{array}{l}\text { Groups differed significantly } \\
\text { by race, mode of injury, } \\
\text { alcohol intoxication }\end{array}$ & $\begin{array}{l}41(50 \%) \text { vs } 35(76 \%) \\
(p=0.004) \\
\text { Functional recovery } 33 \% \\
\text { direct group vs } 15 \% \text { transfer } \\
\text { group } \\
\text { Severe disability/vegetative } \\
\text { state } 17 \% \text { direct group vs } 9 \% \\
\text { transfer group }\end{array}$ & $\begin{array}{l}\text { No multivariate adjustment for } \\
\text { potential confounders }\end{array}$ \\
\hline $\begin{array}{l}\text { Timberlake }(1987)^{66} \\
\text { January I, } 1990 \text { to } \\
\text { December 31, } 1994\end{array}$ & $\begin{array}{l}\text { Trauma registry queried and } \\
\text { patients' hospital records } \\
\text { reviewed } \\
\text { Ethics approval not reported }\end{array}$ & $\begin{array}{l}39(0.64 \%) \text { patients with } \\
\text { blunt pancreas injury } \\
\text { Direct group }=28(72 \%) \\
\text { Transfer group }=11(28 \%) \\
2(18 \%) \text { patients underwent } \\
\text { surgery prior to transfer }\end{array}$ & $\begin{array}{l}\text { Mechanism of injury } 34 \text { (87\%) } \\
\text { MNA, } 3(8 \%) \text { motorcycle } \\
\text { crashes, } 2(5 \%) \text { other } \\
\text { No statistically significant } \\
\text { differences between the } \\
\text { groups other than delay to } \\
\text { definitive care }\end{array}$ & $\begin{array}{l}\text { Mortality direct group } 2(7 \%) \\
\text { cases and } 2(18 \%) \text { in transfer } \\
\text { group }(p=0.66) \\
\text { Hospital LOS for direct group } \\
26 \text { days and } 20 \text { days for } \\
\text { transfer group }\end{array}$ & $\begin{array}{l}\text { No multivariate adjustment for } \\
\text { potential confounders }\end{array}$ \\
\hline $\begin{array}{l}\text { Young et al. (1998) } \\
\text { July 1994-October } \\
1995 \text { (15 months) }\end{array}$ & $\begin{array}{l}\text { Trauma registry, medical } \\
\text { records to verify missing data } \\
\text { Ethics approval not reported }\end{array}$ & $\begin{array}{l}\text { Direct group=165 (137 } \\
\text { sunvived } 24+\text { hours) } \\
\text { Transfer group=151 (135 } \\
\text { sunvived } 24+\text { hours) } \\
\text { Adult trauma patients, age }>18 \\
\text { and ISS }>15\end{array}$ & $\begin{array}{l}\text { Direct group lower GCS, SBP } \\
\text { on arrival to ED and RTS }\end{array}$ & $\begin{array}{l}\text { Hospital mortality } \\
38(23 \%) \text { vs } 28 \text { (19\%) NS } \\
\text { Patients sunvived >24 hours } \\
10(7 \%) \text { vs } 12(9 \%)(p=0.63)\end{array}$ & $\begin{array}{l}\text { No multivariate adjustment for } \\
\text { potential confounders }\end{array}$ \\
\hline
\end{tabular}




\begin{tabular}{|c|c|c|c|c|c|}
\hline Canada & & & & & \\
\hline $\begin{array}{l}\text { Bell et al. (2012) }{ }^{47} \\
\text { Jan. 1, 2001- Mar. } \\
\text { 31, } 2006\end{array}$ & $\begin{array}{l}\text { British Columbia Trauma } \\
\text { Registry } \\
\text { Prehospital and in-transit } \\
\text { deaths and deaths in other } \\
\text { facilities identified from } \\
\text { provincial Coroner Senvice } \\
\text { database } \\
\text { Place of injury identified } \\
\text { through data linkage with } \\
\text { census records } \\
\text { Ethics approval }\end{array}$ & $\begin{array}{l}\text { Patients aged >= } 18 \text { years } \\
\text { with severe thermal burns } \\
\text { referred or transported } \\
\text { directly to burns centre } \\
\text { Excluded hospital admissions } \\
\text { and deaths from hypothermia } \\
\text { and intentional self-harm, } \\
\text { patients treated and } \\
\text { discharged on the same day } \\
\text { or outpatients treated for } \\
\text { burns in ED or burn clinic } \\
\text { Direct group = } 60 \text { patients } \\
\text { Transfer group = } 104 \text { patients } \\
\text { Air transport direct group } 7 \\
\text { (12\%) patients, transfer group } \\
63 \text { (60\%) patients } \\
\text { No missing data reported }\end{array}$ & $\begin{array}{l}\text { Significant difference in age, } \\
\text { intubated before transport, } \\
\text { use of fixed wing aircraft, rural } \\
\text { cases, transport times } \\
\text { between groups }\end{array}$ & $\begin{array}{l}\text { Bivariate analysis for } \\
\text { continuous and discrete } \\
\text { variables } \\
\text { Relative risk (RR) of } \\
\text { prehospital and in-hospital } \\
\text { mortality and hospital stay by } \\
\text { transport status Poisson } \\
\text { regression model } \\
\text { Patient hospital mortality after } \\
72 \text { hours: direct group = } 11 \\
\text { (18.3\%), transfer group =9 } \\
\text { (8.6\%) } \\
\text { In-hospital mortality } 15(25 \%) \\
\text { for direct admissions and } 18 \\
\text { (17\%) for transfers }\end{array}$ & $\begin{array}{l}\text { Covariates - site where } \\
\text { definitive care delivered, age, } \\
\text { sex, ISS, inhalation injury, } \\
\text { intubation, mode of transport, } \\
\text { transport time, burn total body } \\
\text { surface area, rural and urban } \\
\text { injury location, and injury } \\
\text { mechanism } \\
\text { After controlling for patient } \\
\text { and injury characteristics, } \\
\text { transfer group associated with } \\
\text { in-hospital death (RR 1.32, } \\
\text { 95\% Cl 0.54- 3.22) or hospital } \\
\text { stay (RR 0.96, 95\% Cl 0.65- } \\
\text { 1.42) } \\
\text { Rural populations } \\
\text { experienced an increased risk } \\
\text { of total mortality (RR 1.22, } \\
\text { 95\% Cl 1.00-1.48) }\end{array}$ \\
\hline $\begin{array}{l}\text { Haas et al. (2010) }{ }^{18} \\
\text { July } 2002 \text { - } \\
\text { December } 2007\end{array}$ & $\begin{array}{l}\text { Population-based study } \\
\text { Retrospective cohort design } \\
\text { Data source centralized } \\
\text { administrative health } \\
\text { databases, including National } \\
\text { Ambulatory Care Reporting } \\
\text { System } \\
\text { Ethics approval }\end{array}$ & $\begin{array}{l}\text { Severely injured patients } \\
\text { aged } 18+\text { years and surviving } \\
\text { to ED } \\
\text { Severe injury=ISS > } 15 \text { or } \\
\text { death within } 24 \text { hours of } \\
\text { presentation } \\
\text { Direct cohort=7481 (66\%) } \\
\text { patients } \\
\text { Undertriage cohort =3917 } \\
\text { patients initially triaged to } \\
\text { non-TC: } \\
\text { - } 3469 \text { (30\%) =transfer group } \\
\text { - } 448 \text { (4\%). died before } \\
\text { transfer could be } \\
\text { accomplished =ED death } \\
\text { group }\end{array}$ & $\begin{array}{l}\text { Undertriage and direct } \\
\text { cohorts similar demographic } \\
\text { characteristics, but patients in } \\
\text { direct cohort had more } \\
\text { penetrating injuries and lower } \\
\text { ISS } \\
\text { Patients who died before } \\
\text { successful transfer more } \\
\text { likely to be female, older, } \\
\text { have comorbidities, } \\
\text { penetrating trauma, and } \\
\text { severe head injuries }\end{array}$ & $\begin{array}{l}\text { 30-day mortality } \\
1192(16 \%) \text { vs } 425 \text { (12\%) } \\
\text { (unadjusted OR 0.74; 95\% Cl } \\
0.65-0.83 \text { ) } \\
\text { Including deaths at secondary } \\
\text { hospital 30-day mortality, i.e. } \\
\text { undertriage } \\
1192 \text { (16\%) vs } 873 \text { (22\%) } \\
\text { Unadjusted OR (1.51, 95\% Cl } \\
\text { 1.37-1.67) }\end{array}$ & $\begin{array}{l}30 \text { day-mortality (OR 0.91; } \\
95 \% \text { Cl 0.80-1.04) in transfer } \\
\text { cohort vs direct cohort } \\
\text { Adjusted OR transfer vs direct } \\
\text { cohort } 1.24 \text { (95\% Cl, 1.10- } \\
\text { 1.40) } \\
\text { Adjusted for age; gender; } \\
\text { Charlson score; mechanism } \\
\text { of injury; ISS; and severe } \\
\text { injury (AS >-3) in the head, } \\
\text { chest, and abdomen region }\end{array}$ \\
\hline
\end{tabular}




\begin{tabular}{|c|c|c|c|c|c|}
\hline & & $\begin{array}{l}\text { Excluded: burns, foreign } \\
\text { bodies, poisonings, toxic } \\
\text { effects, suffocation, drowning, } \\
\text { and complications of medical/ } \\
\text { surgical care; presented with } \\
\text { injury diagnosis code within } 3 \\
\text { months of index event and } \\
\text { patients DOA to ED or died } \\
\text { within } 30 \text { minutes of ED } \\
\text { presentation; died in ED after } \\
\text { triaged non-urgent (CTAS } 4 \\
\text { or 5) or admitted to non- } \\
\text { trauma center }\end{array}$ & & & \\
\hline $\begin{array}{l}\text { Haas et al. }(2012)^{20} \\
2002-2010\end{array}$ & $\begin{array}{l}\text { Population-based, } \\
\text { retrospective cohort study } \\
\text { Data derived from } \\
\text { administrative databases } \\
\text { capturing all emergency } \\
\text { department deaths and } \\
\text { admissions in the region } \\
\text { Ethics approval }\end{array}$ & $\begin{array}{l}\text { MNA occupants, aged } \\
\text { 18+,presenting to ED with } \\
\text { severe injury ISS >= } 15 \text { or } \\
\text { death vithin } 24 \text { hours of } \\
\text { presentation } \\
\text { Excluded discharges home } \\
\text { from ED, patients with an } \\
\text { injury-related ED visit in the } 3 \\
\text { months before index event, } \\
\text { died at scene, DOA or who } \\
\text { died within } 30 \text { minutes of ED } \\
\text { presentation, patients } \\
\text { transferred more than once } \\
6,341 \text { MNA occupants: Direct } \\
\text { group 2,857 patients (45\%) } \\
\text { transfer group within } 24 \text { hours } \\
2,003 \text { patients (57\%) } \\
\text { Missing ISS data - direct } 54 \text {, } \\
\text { transfer } 136 \text { patients } \\
\text { Transport mode not reported }\end{array}$ & $\begin{array}{l}\text { Transfer group older, lower } \\
\text { ISS (more missing or low ISS } \\
\text { because of greater number of } \\
\text { early deaths within } 24 \text { hours } \\
\text { of presentation) but included } \\
\text { patients not transferred to } \\
\text { trauma centre }(n=1,481)\end{array}$ & $\begin{array}{l}\text { Unadjusted mortality } \\
\text { ED 2\% vs 4\% } \\
\text { 24-hour 6\% vs 7\% } \\
\text { 48-hour } 8 \% \text { vs } 9 \% \\
\text { 7-day 10\% both groups } \\
\text { 30-day 12\% both groups }\end{array}$ & $\begin{array}{l}\text { Compared to transfer group, } \\
\text { adjusted mortality for direct } \\
\text { group at } \\
24 \text { hours OR } 0.58,95 \% \mathrm{Cl} \\
0.41-0.84 \\
48 \text { hours OR } 0.68,95 \% \mathrm{Cl} \\
0.48-0.96 \\
7 \text { days OR } 0.76,95 \% \mathrm{Cl} 0.55- \\
1.05 \\
30 \text { days OR } 0.68,95 \% \mathrm{Cl} \\
0.48-0.96 \text { ) }\end{array}$ \\
\hline $\begin{array}{l}\text { Sampalis et al. } \\
(1997)^{28} \\
\text { April 1993-Dec } 1995 \\
\text { (33 months) }\end{array}$ & $\begin{array}{l}\text { Prospective multicentre } \\
\text { observational study } \\
\text { Trauma Registry review }\end{array}$ & $\begin{array}{l}\text { 4,364 patients including } \\
\text { children } \\
\text { Included: injured within city } \\
\text { limits, transported to hospital }\end{array}$ & $\begin{array}{l}\text { Transfer group younger, more } \\
\text { males, more head/neck } \\
\text { injuries (56\% vs 28\%). Similar } \\
\text { ISS, TRS, PHI }\end{array}$ & $\begin{array}{l}\text { Hospital mortality } \\
4.8 \% \text { vs } 8.9 \%(p<0.003) \\
\text { Mortality after admission }\end{array}$ & $\begin{array}{l}\text { Adjusted overall mortality OR } \\
1.57 ; 95 \% \mathrm{Cl}=1.17-2.08, \\
\mathrm{p}=0.02 \\
\text { Adjusted for age, injury }\end{array}$ \\
\hline
\end{tabular}




\begin{tabular}{|c|c|c|c|c|c|}
\hline & Ethics approval not reported & $\begin{array}{l}\text { by local EMS; alive on arrival } \\
\text { to hospital PLUS death as a } \\
\text { result of the injury or hospital } \\
\text { stay >3 days or ICU } \\
\text { admission } \\
\text { Direct group } 2,756(63 \%) \\
\text { Transfer group 1,608 (37\%) } \\
\text { Of the transfers, } 437 \text { ( } 27 \%) \\
\text { from secondary centre and } \\
1,171 \text { (73\%) from primary } \\
\text { hospitals }\end{array}$ & & $3.6 \%$ vs $5.5 \%(p<0.003)$ & $\begin{array}{l}\text { severity, sex, MOI, body } \\
\text { region }\end{array}$ \\
\hline \multicolumn{6}{|l|}{ Europe } \\
\hline $\begin{array}{l}\text { de Jongh et al., } \\
2008^{79} \\
\text { January } 2000 \text { - } \\
\text { September } 2006\end{array}$ & $\begin{array}{l}\text { Dutch trauma registry data, } \\
\text { based on Major Trauma } \\
\text { Outcome Study (MTOS) }{ }^{81} \\
\text { Mixture of prospective and } \\
\text { retrospective registry data } \\
\text { from } 12 \text { of } 15 \text { EDs } \\
\text { Compared outcomes with } \\
\text { existing norms for England } \\
\text { and Wales } \\
\text { Ethics approval not reported }\end{array}$ & $\begin{array}{l}\text { All trauma patients admitted } \\
\text { from ED } \\
17,023 \text { records with complete } \\
\text { information of } 25,445 \\
\text { admissions from } 12 \text { EDs } \\
451 \text { patients major trauma } \\
\text { ISS } 15 \text { transported to level I } \\
\text { trauma centre (direct } \\
\text { group=382, transfer } \\
\text { group=69) } \\
\text { Included trauma patients } \\
\text { admitted immediately or } \\
\text { following transfer from } \\
\text { another hospital or DOA or } \\
\text { died in ED } \\
\text { Excluded patients with } \\
\text { missing values for ISS } \\
\text { ( } \mathrm{n}=1395 \text { ), GCS, outcome } \\
\text { (mortality or length of stay } \\
\mathrm{n}=4230 \text { ), type of injury (blunt } \\
\text { or penetrating), age ( } \mathrm{n}=95 \text { ) or } \\
\text { transfer; patients who } \\
\text { survived admission in the } \\
\text { trauma centre and transferred } \\
\text { within } 30 \text { days to another }\end{array}$ & $\begin{array}{l}\text { Transfer group had more } \\
\text { severe brain injury ( } 75 \% \text { vs } \\
53 \% \text { direct group) }\end{array}$ & $\begin{array}{l}\text { In-hospital death within } 30 \\
\text { days direct group } 110(29 \%) \text {, } \\
\text { transfer group } 15(22 \%) \\
\text { Compared with transfer } \\
\text { group, unadjusted OR 1.5; } \\
95 \% \text { Cl } 0.8-2.7\end{array}$ & $\begin{array}{l}\text { Adjusted for age, severe brain } \\
\text { injury, ISS and GCS } \\
\text { Direct group compared to } \\
\text { transfer group adjusted OR } \\
\text { 1.9; } 95 \% \mathrm{Cl} 0.9-4.1\end{array}$ \\
\hline
\end{tabular}


institution (outcome unknown)

Transport mode not described

\begin{tabular}{|c|c|c|c|c|c|}
\hline \multirow[b]{2}{*}{$\begin{array}{l}\text { Joosse et al. (2012) })^{54} \\
\text { January 1, 2006 - } \\
\text { December 31, } 2009\end{array}$} & & Transport mode not described & & & \\
\hline & $\begin{array}{l}\text { Retrospective study } \\
\text { Trauma registry used to } \\
\text { identify patients } \\
\text { Chart review } \\
\text { GOS assessed by reviewing } \\
\text { the latest hospital and general } \\
\text { practitioner's correspondence } \\
\text { Ethics approval not reported }\end{array}$ & $\begin{array}{l}\text { Patients with severe TBI (AIS } \\
\text { of the head score }>=3 \text { ) and } \\
\text { underwent neurosurgery } \\
\text { within } 6 \text { hours after admission } \\
\text { to Level I trauma center } \\
\text { Direct group n=56, transfer } \\
\text { group (transferred to Level I } \\
\text { trauma center after neuro- } \\
\text { surgical intervention) n=24 } \\
\text { Excluded patients operated } \\
\text { for insertion of intracranial } \\
\text { pressure monitoring device or } \\
\text { external ventricular drains } \\
\text { only, admitted for observation } \\
\text { but requiring a secondary } \\
\text { emergency operation, } \\
\text { required surgery after clinical } \\
\text { deterioration, or patients } \\
\text { dying of uncontrollable } \\
\text { bleeding outside the brain } \\
\text { No missing data reported }\end{array}$ & $\begin{array}{l}\text { Prehospital GCS score was } \\
\text { higher in the transfer group }(p \\
=0.02) \\
\text { Transfer group had lower } \\
\text { score in almost all injury types }\end{array}$ & $\begin{array}{l}\text { 30-day mortality direct group } \\
15(27 \%) \text { vs transfer group } 8 \\
(33 \%, p=0.55) \\
\text { Direct group had a worse } \\
\text { GOS on-scene but did not } \\
\text { differ overall }(p=0.87)\end{array}$ & $\begin{array}{l}\text { No multivariate adjustment for } \\
\text { potential confounders }\end{array}$ \\
\hline $\begin{array}{l}\text { Moen et al. }(2008)^{16} \\
\text { 1998-2002 }\end{array}$ & $\begin{array}{l}\text { Retrospective analysis } \\
\text { Ambulance and hospital } \\
\text { records } \\
\text { Direct group: } 79 \% \text { air } \\
\text { ambulance or ambulance with } \\
\text { anaesthesiologist compared } \\
\text { with } 26 \% \text { of the patients } \\
\text { transported to local hospital } \\
\text { (p<0.001) } \\
95 \% \text { of transfer group from } \\
\text { secondary hospital to TC by } \\
\text { air ambulance senvices } \\
\text { Ethics approval }\end{array}$ & $\begin{array}{l}146 \text { patients with severe TBI } \\
\text { (GCS<=8) } 83 \text { patients in } \\
\text { direct group, } 63 \text { patients in } \\
\text { transfer group } \\
9 \text { patients bilaterally fixed } \\
\text { dilated pupils, GCS = } 3 \text { and } \\
\text { CT scan shoving signs of } \\
\text { herniation on admission and } 2 \\
\text { patients died within } 24 \text { hours } \\
\text { because of other injuries } \\
\text { included in analyses of } \\
\text { transportation, but excluded } \\
\text { from analyses of surgical } \\
\text { treatment, outcome and death }\end{array}$ & $\begin{array}{l}\text { Transfer TBI group (43\%) had } \\
\text { fewer MNA injuries, higher } \\
\text { field GCS, lower ISS, fewer } \\
\text { pre-hospital intubations }\end{array}$ & $\begin{array}{l}\text { 6-month mortality } \\
23(31 \%) \text { vs } 9(15 \%) \\
(p<0.001)\end{array}$ & $\begin{array}{l}\text { 6-month mortality not } \\
\text { increased for transfer group } \\
\text { (OR } 0.43,0.16,1.14, p=0.09 \text { ) } \\
\text { Adjusted for age, GCS and } \\
\text { pupillary abnormalities }\end{array}$ \\
\hline
\end{tabular}




\begin{tabular}{|c|c|c|c|c|c|}
\hline & & $\begin{array}{l}\text { Median age } 34 \text { (1-88) years, } \\
\text { Children included ( } 19 \\
\text { patients }<16 \text { years) }\end{array}$ & & & \\
\hline $\begin{array}{l}\text { Nardi et al. }(1994)^{58} \\
1 \text { August } 1992 \text { to } 28 \\
\text { February1993 }\end{array}$ & $\begin{array}{l}\text { Prospective study, collected } \\
\text { data entered into study } \\
\text { database } \\
\text { Single EMS - controls all } \\
\text { ambulances and HEMS, } \\
\text { Decision to call HEMS at } \\
\text { discretion of ambulance crew } \\
\text { on arrival to scene } \\
\text { Ethics approval not reported }\end{array}$ & $\begin{array}{l}222 \text { severe trauma patients } \\
\text { from road traffic, work and } \\
\text { sport accidents with ISS }>15 \text {, } \\
\text { ICU admission } 48+\text { hours in } \\
\text { level I/II trauma center, } \\
\text { received ventilatory support } \\
\text { and alive at time of arrival of } \\
\text { first rescuers } \\
\text { Direct group ; } 98 \text { patients } \\
\text { Transfer group } 82 \text { patients } \\
\text { HEMS group: } 42 \text { patients } \\
\text { transported by HEMS team }\end{array}$ & $\begin{array}{l}\text { 95\%MNA } \\
\text { No differences in age, sex, } \\
\text { ISS or level I/II trauma center } \\
\text { Mean ISS direct group } 35.1 \\
\text { +/- 18.2, transfer group } 33.4 \\
+/-19.6\end{array}$ & $\begin{array}{l}\text { Followed up to discharge } \\
\text { from ICU } \\
\text { Mortality: } \\
\text { Direct group } 31 \text { (38\%), } 23 \\
\text { died before trauma center } \\
\text { arrival } \\
\text { Transfer group } 31 \text { (32\%) } \\
\text { Mean ICU LOS for ICU } \\
\text { survivors } \\
\text { Direct group = } 15 \text { days } \\
\text { Transfer group = } 13 \text { days }\end{array}$ & $\begin{array}{l}\text { No multivariate adjustment for } \\
\text { potential confounders }\end{array}$ \\
\hline $\begin{array}{l}\text { Osterwalder et al. } \\
(2002)^{61} \\
\text { June 15, 1990, and } \\
\text { June 15, } 1996\end{array}$ & $\begin{array}{l}\text { Prospective observational } \\
\text { cohort study of trauma } \\
\text { registry data } \\
\text { Sunvival data from hospital, } \\
\text { third-party medical records } \\
\text { and citizen's registration } \\
\text { offices } \\
\text { Primary rescue for } 300 \text { (64\%) } \\
\text { injured patients by ground } \\
\text { senvices, } 170 \text { (36\%) rescued } \\
\text { by helicopter } \\
\text { Ethics approval not reported }\end{array}$ & $\begin{array}{l}\text { Included blunt trauma, } \\
\text { treatment in shock room, } \\
\text { presence of injuries with } \\
\text { minimum AIS 2+ in at least } \\
\text { two of six defined body } \\
\text { regions (without external } \\
\text { system AS-6), transfer to ICU } \\
\text { or hospital stay 3+ days, or } \\
\text { death after admission, ISS 8+ } \\
\text { Direct group } 280 \text { patients } \\
\text { Transfer group } 190 \text { patients }\end{array}$ & $\begin{array}{l}\text { Groups differed in age, } \\
\text { causes of the trauma (sport, } \\
\text { falls) and rescue times }\end{array}$ & $\begin{array}{l}\text { Mortality for direct group } 33 \\
(12 \%), \text { and transfer group } 27 \\
(14 \%)\end{array}$ & $\begin{array}{l}\text { No multivariate adjustment for } \\
\text { potential confounders }\end{array}$ \\
\hline $\begin{array}{l}\text { Sollid et al. (2003) } \\
\text { 1986-1995 (10 years) }\end{array}$ & $\begin{array}{l}\text { Retrospective review of } \\
\text { ambulance records, transfer } \\
\text { notes, and hospital records } \\
\text { Mode of transport: } \\
\text { Direct group - ground 34\%, } \\
\text { rotor 38\%, fixed wing 28\% } \\
\text { Transfer group: rotor 16\%, } \\
\text { fixed wing 84\% }\end{array}$ & $\begin{array}{l}85 \text { patients with severe TBI } \\
\text { operated for intracranial mass } \\
\text { lesions within } 48 \text { hours after } \\
\text { injury } \\
\text { Excluded: } 33 \text { patients } \\
\text { operated for depressed or } \\
\text { open skull fractures vithout } \\
\text { intracranial mass lesions, } 1 \\
\text { patient operated with }\end{array}$ & $\begin{array}{l}\text { No differences in admission } \\
\text { GCS scores, type of injury or } \\
\text { the proportion of patients vith } \\
\text { multitrauma }\end{array}$ & $\begin{array}{l}16(34 \%) \text { vs } 10 \text { ( } 26 \%) \\
2 \text { to } 76 \text { months post-injury for } \\
83 \text { patients - direct group } \\
\text { good outcomes } 53 \% \text { vs } 58 \%\end{array}$ & $\begin{array}{l}\text { No multivariate adjustment for } \\
\text { potential confounders }\end{array}$ \\
\hline
\end{tabular}




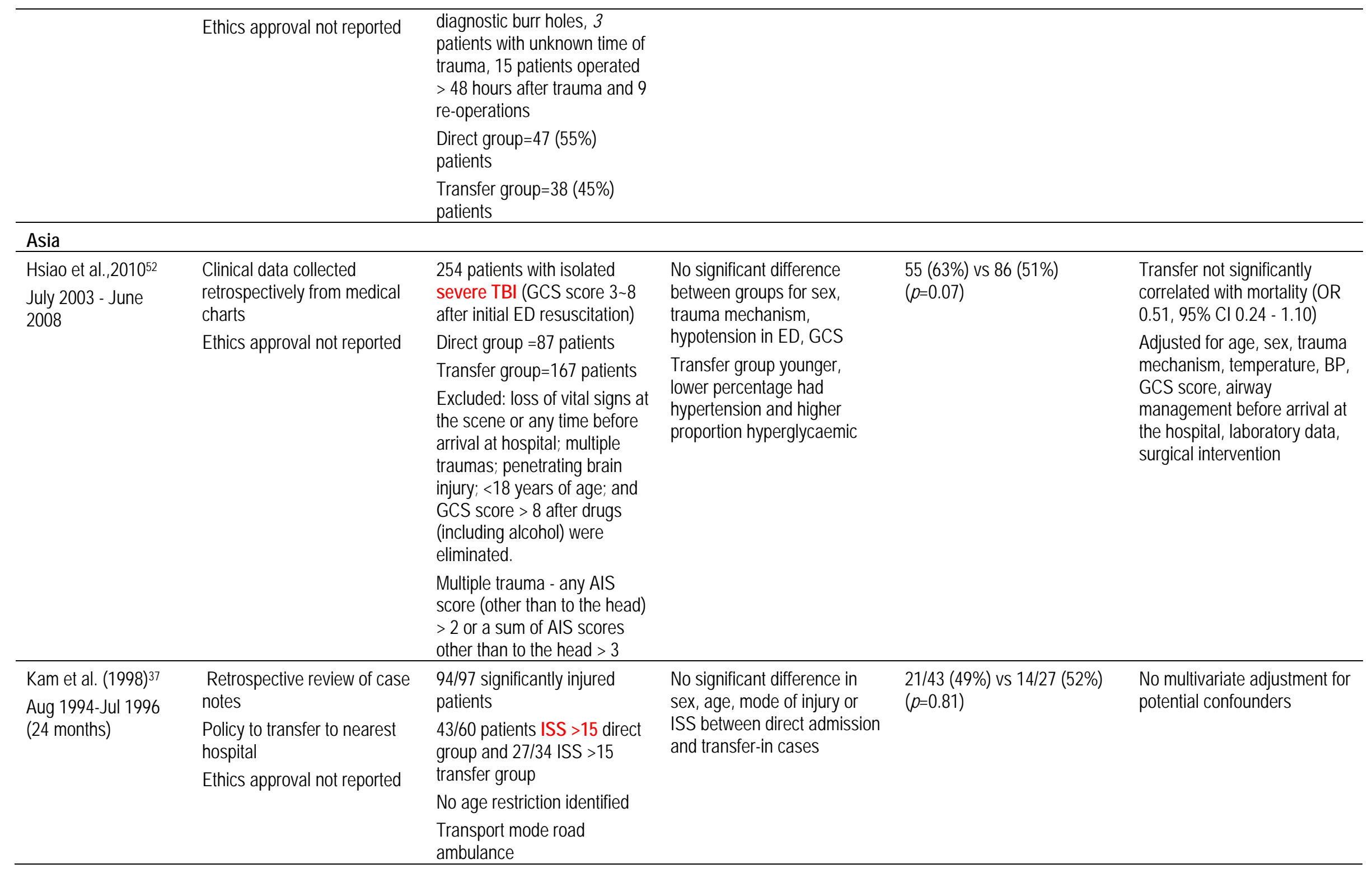




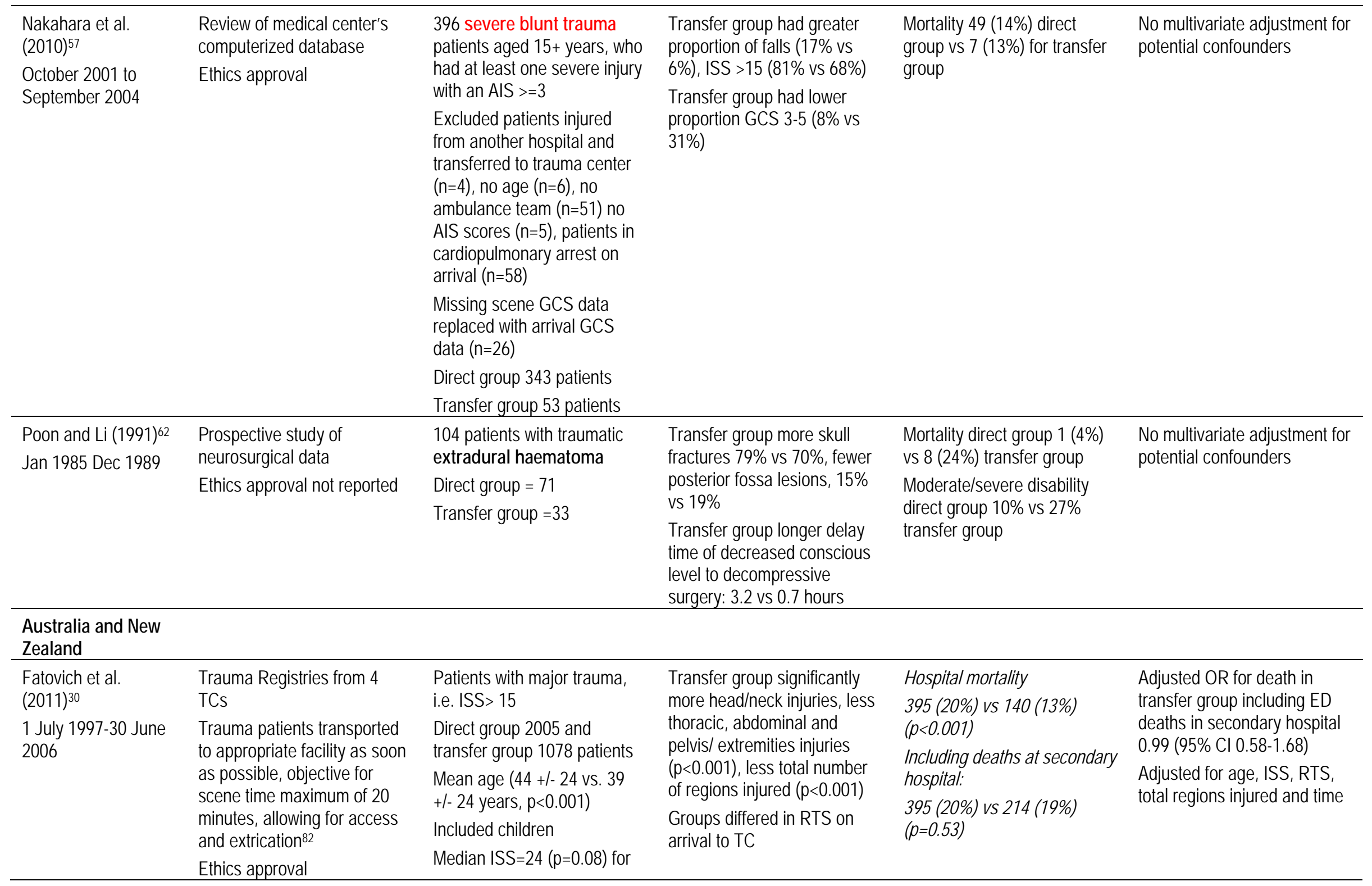




\begin{tabular}{|c|c|c|c|c|c|}
\hline & & both groups & & $17(18 \%)$ vs $7(10 \%)(p=0.1)$ & $\begin{array}{l}\text { No multivariate adjustment for } \\
\text { potential confounders }\end{array}$ \\
\hline \multirow{5}{*}{$\begin{array}{l}\text { Kejriwal \& Civil } \\
(2009)^{55} \\
2004\end{array}$} & \multirow[t]{5}{*}{$\begin{array}{l}\text { Trauma Registry data } \\
\text { Ethics approval not reported }\end{array}$} & \multirow{5}{*}{$\begin{array}{l}198 \text { adult patients in trauma } \\
\text { registry with moderate or } \\
\text { severe TBI, ASS score >=f } 3 \\
97 \text { direct group and } 73 \\
\text { transfer group } \\
\text { Patients transferred >24 } \\
\text { hours or without time of injury } \\
\text { or time of arrival excluded } \\
\text { (15\%) } \\
\text { Transport by road ambulance } \\
89 \% \text { direct group and } 88 \% \\
\text { indirect group }\end{array}$} & \multirow{5}{*}{$\begin{array}{l}\text { Significant difference in age, } \\
\text { MNA and multitrauma } \\
\text { between TBI groups }\end{array}$} & \multirow[t]{5}{*}{17 (18\%) vs 7 (10\%) (p=0.1) } & \multirow[t]{5}{*}{$\begin{array}{l}\text { No multivariate adjustment for } \\
\text { potential confounders }\end{array}$} \\
\hline & & & & & \\
\hline & & & & & \\
\hline & & & & & \\
\hline & & & & & \\
\hline \multicolumn{6}{|l|}{ South Africa } \\
\hline \multirow{9}{*}{$\begin{array}{l}\text { Cheddie et al. } \\
(2011)^{48} \\
\text { March } 2007 \text { to } \\
\text { December } 2008\end{array}$} & \multirow{9}{*}{$\begin{array}{l}\text { Data retrieved from hospital } \\
\text { informatics system and an } \\
\text { independent database in the } \\
\text { trauma unit } \\
\text { interhospital } \\
\text { Ethics approval }\end{array}$} & 407 severely injured patients: & \multirow{9}{*}{$\begin{array}{l}\text { No significant differences in } \\
\text { age, gender but significantly } \\
\text { more penetrating trauma, less } \\
\text { MNA-related injuries and } \\
\text { lower ISS in transfer group } \\
\text { (25 vs 20; p<0.02) }\end{array}$} & Hospital mortality & \multirow{9}{*}{$\begin{array}{l}\text { No multivariate adjustment for } \\
\text { potential confounders }\end{array}$} \\
\hline & & 118 (29\%) direct from scene & & $37(31 \%)$ vs 70 (24\%) & \\
\hline & & $\begin{array}{l}\text { and } 289(1 \%) \text { inter-hospital } \\
\text { transfers }\end{array}$ & & $(p=0.19)$ & \\
\hline & & Median age 27 years (range 1 & & Patients sumiving > 12 hours: & \\
\hline & & - 83), $71 \%$ male & & $\begin{array}{l}13(14 \%) \text { vs } 67(23.5 \%) \\
(p=0.04)\end{array}$ & \\
\hline & & $\begin{array}{l}\text { Blunt injury accounted for } \\
66 \% \text { of admissions and MNC } \\
87 \%\end{array}$ & & \multirow[t]{4}{*}{$\begin{array}{l}\text { No significant difference in } \\
\text { mortality between ambulance } \\
\text { vs. air transport }\end{array}$} & \\
\hline & & $\begin{array}{l}\text { Median ISS for cohort = } 22 \\
\text { (survivors 18, deaths } 29 \text {; } \\
p<0.001 \text { ) }\end{array}$ & & & \\
\hline & & $\begin{array}{l}\text { Transfer group accepted at } \\
\text { trauma centre for surgery and } \\
\text { subsequent ICU management } \\
\text { if surgical expertise } \\
\text { unavailable at referral source, } \\
\text { ICU admission following } \\
\text { surgery at another institution, } \\
\text { or for ICU management alone } \\
\text { if surgery not required }\end{array}$ & & & \\
\hline & & Excluded deaths in transfer & & & \\
\hline
\end{tabular}




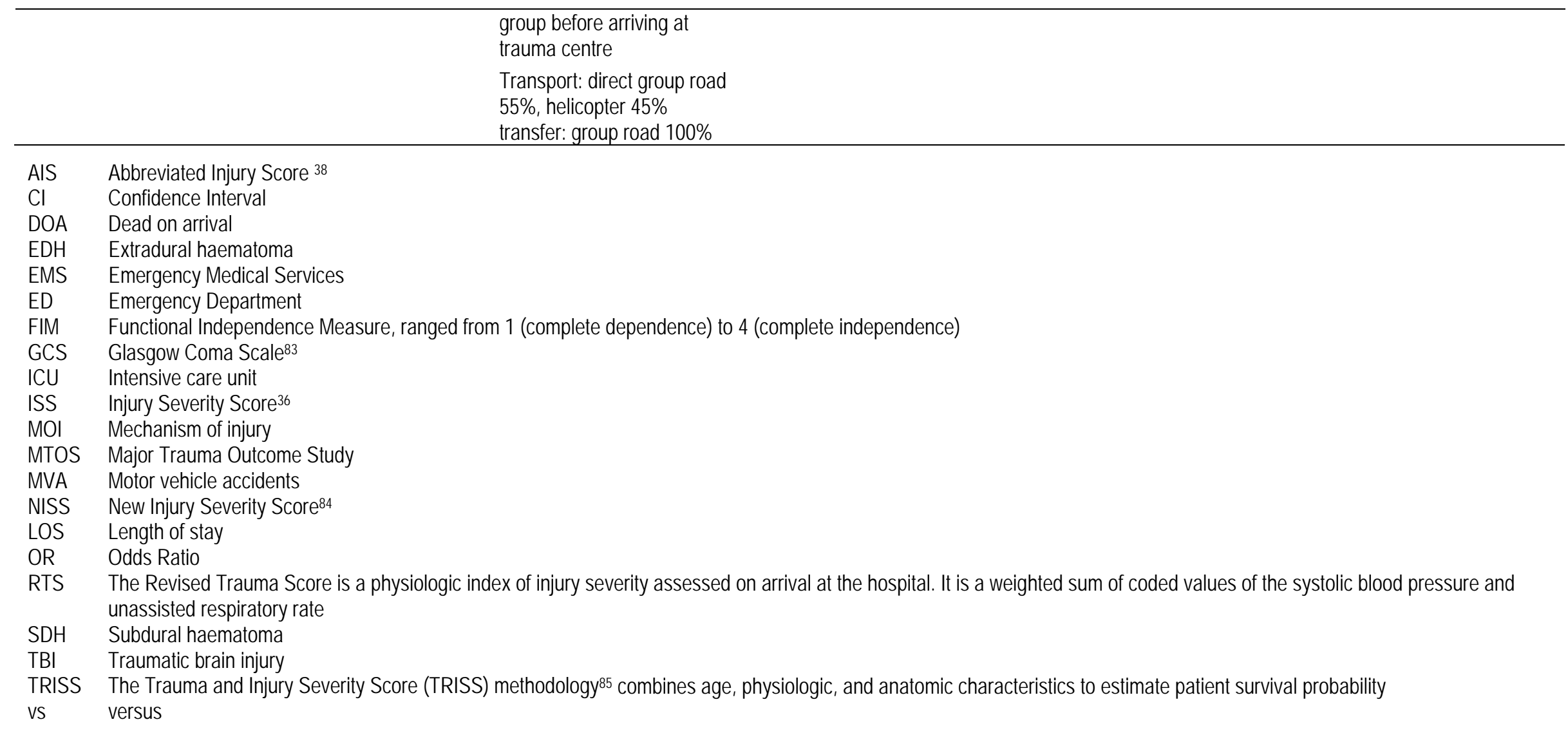


Figure A. Funnel plot to demonstrate presence of publication bias: the vertical axis plots the standard error and the horizontal axis plots the logit event (mortality) rate, defined as logit $(p)=\log$ $(p)-\log (1-p)$, where $p$ is the event (mortality) rate

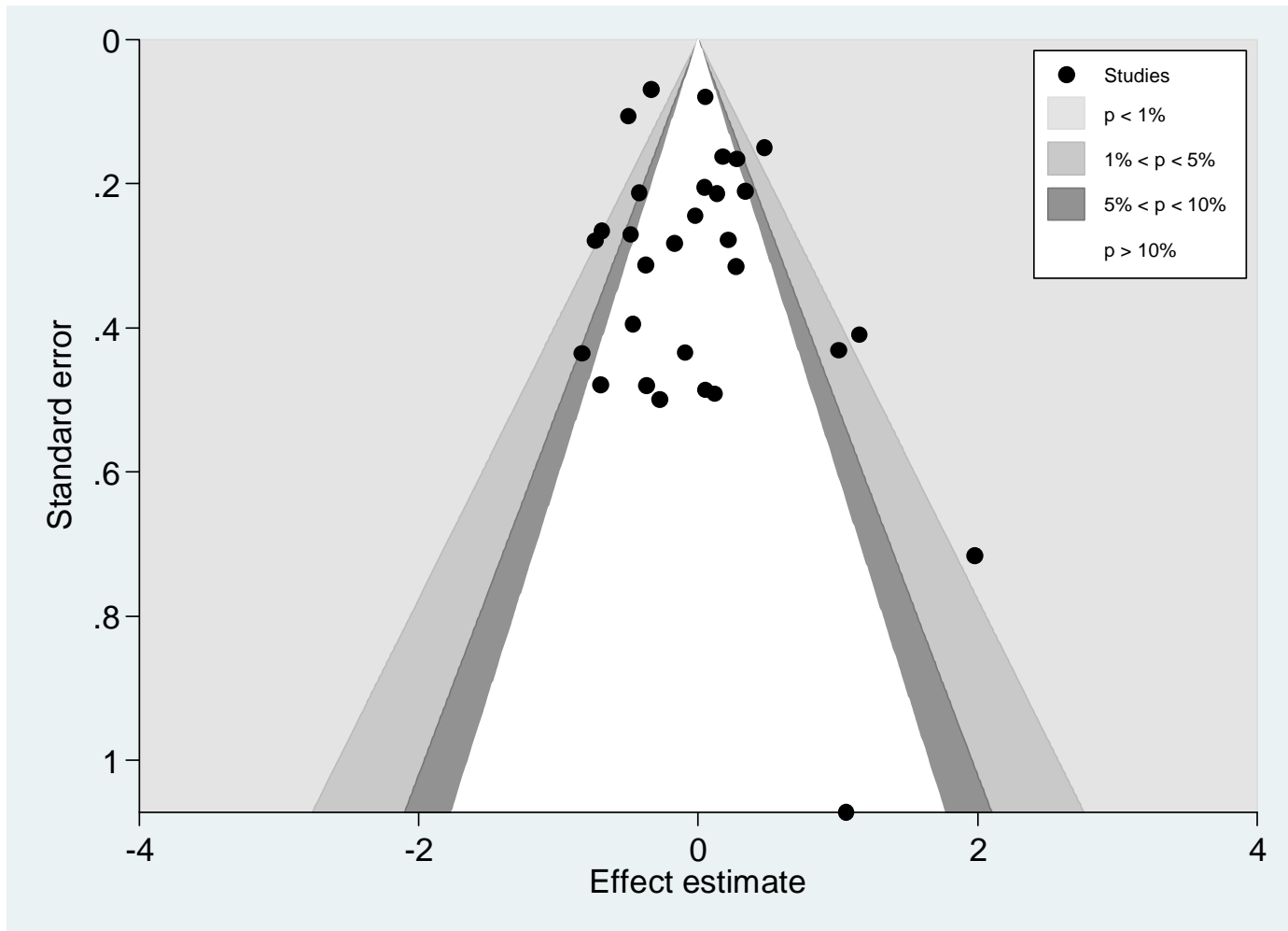


Figure B. Galbraith plot to assess heterogeneity for the 30 studies evaluated

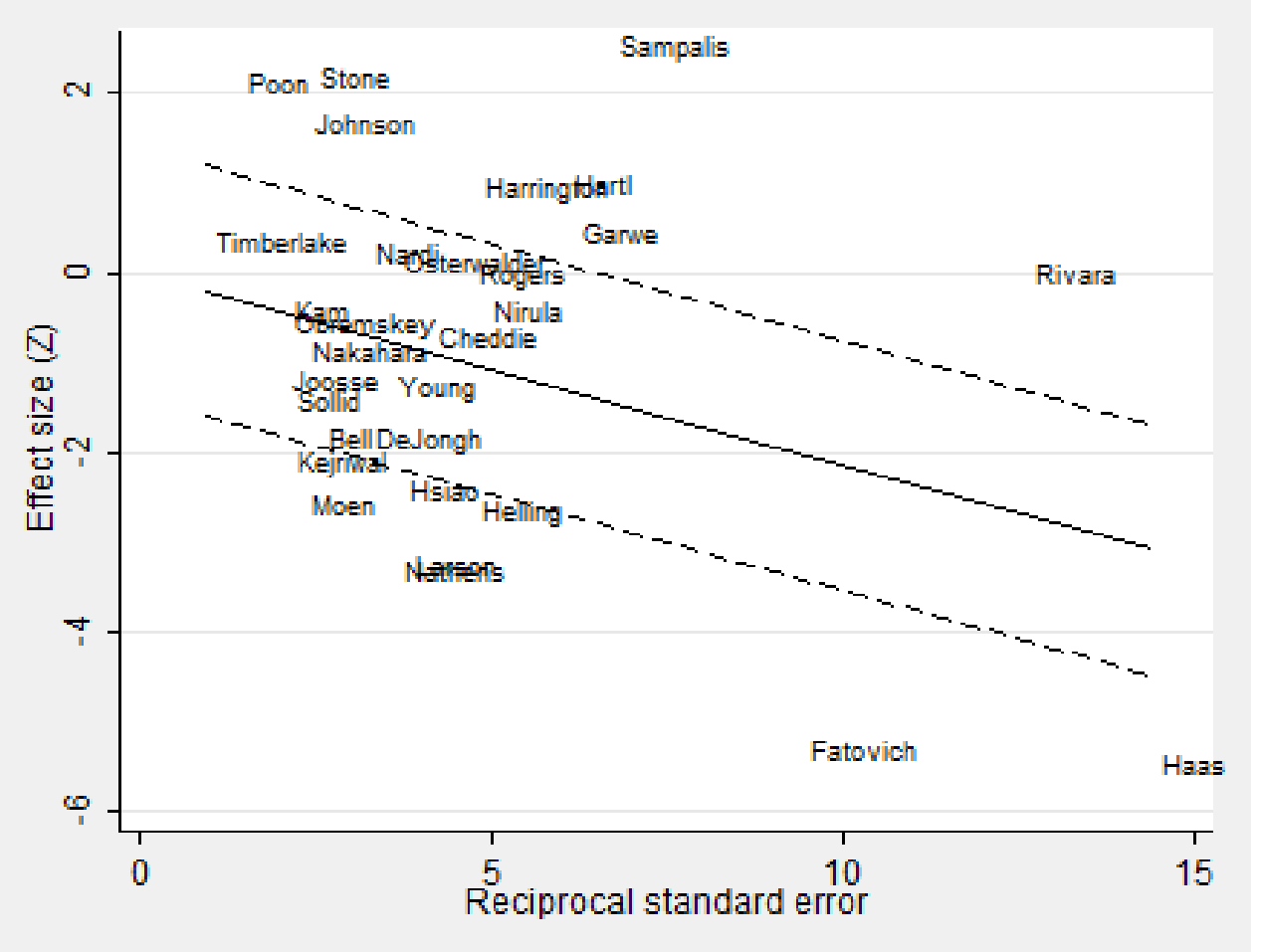


Figure A. Funnel plot to demonstrate presence of publication bias: the vertical axis plots the standard error and the horizontal axis plots the logit event (mortality) rate, defined as logit $(p)=\log$ $(p)-\log (1-p)$, where $p$ is the event (mortality) rate

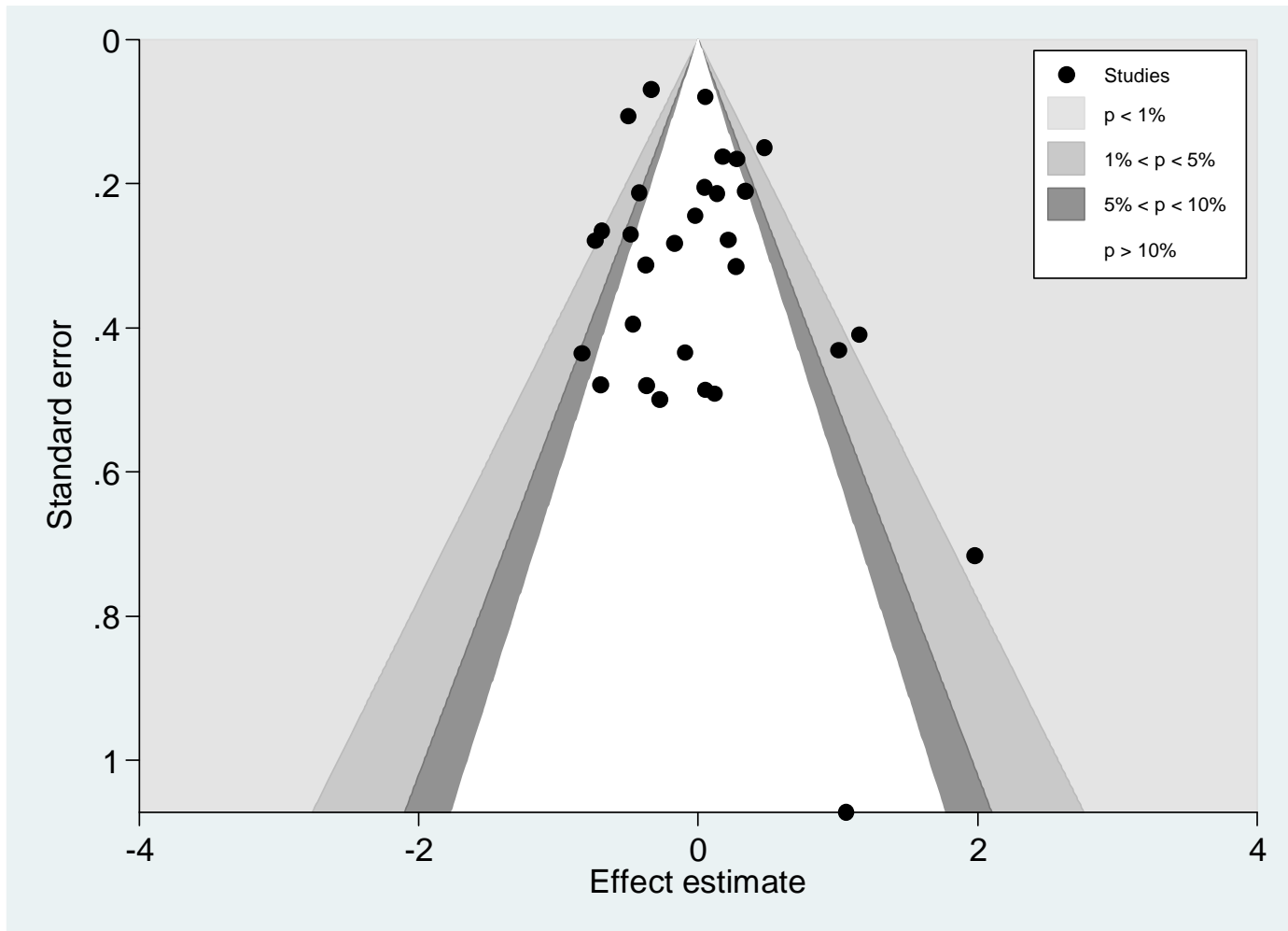


Figure B. Galbraith plot to assess heterogeneity for the 30 studies evaluated

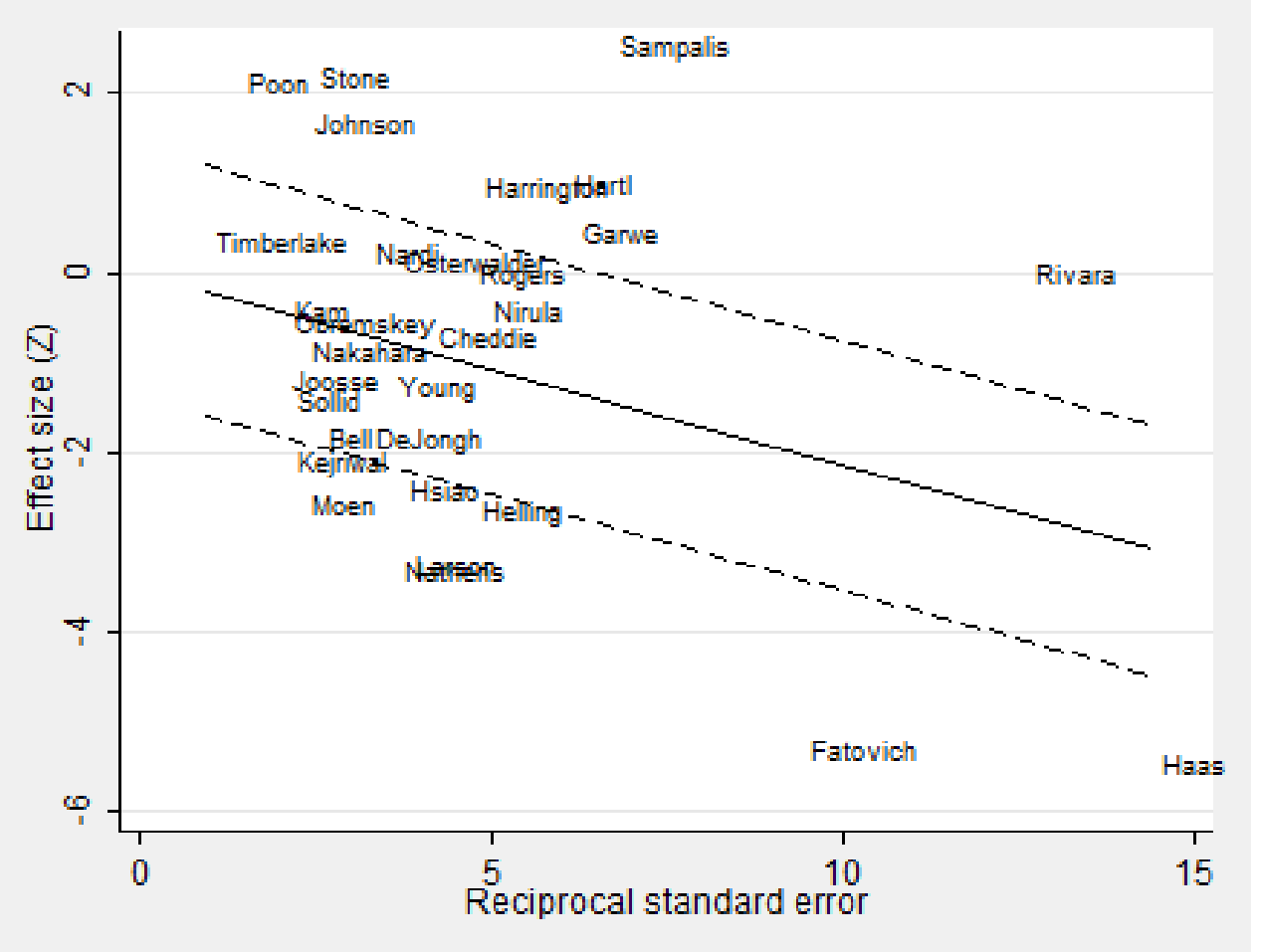

